\title{
Г.В. Скрипникова
}

\section{ЭКОНОМИЧЕСКИЙ АНАЛИЗ}

Учебное пособие для студентов

экономических направлений подготовки бакалавриата 
МИНИСТЕРСТВО НАУКИ И ВЫСШЕГО ОБРАЗОВАНИЯ РФ ФЕДЕРАЛЬНОЕ ГОСУДАРСТВЕННОЕ БЮДЖЕТНОЕ ОБРАЗОВАТЕЛЬНОЕ УЧРЕЖДЕНИЕ ВЫСШЕГО ОБРАЗОВАНИЯ «КЕМЕРОВСКИЙ ГОСУДАРСТВЕННЫЙ УНИВЕРСИТЕТ» БЕЛОВСКИЙ ИНСТИТУТ (ФИЛИАЛ)

\author{
Г.В. Скрипникова
}

\title{
ЭКОНОМИЧЕСКИЙ АНАЛИЗ
}

\author{
Учебное пособие \\ для студентов экономических направлений подготовки \\ бакалавриата
}


Печатается по решению методического совета

Кемеровского государственного университета

\section{Рецензенты:}

Кафедра экономических наук и информационных технологий

Беловского института (филиала) КемГУ;

Е.А. Федулова, доктор экономических наук, профессор, заведующий кафедрой «Финансы и кредит»

ФГБОУ ВО «Кемеровский государственный университет»

\section{Скрипникова, Г.В.}

C45 Экономический анализ: учебное пособие для студентов экономических направлений подготовки бакалавриата / Г.В. Скрипникова; Беловский институт (филиал) федерального государственного бюджетного образовательного учреждения высшего образования «Кемеровский государственный университет» [Электронный ресурс]. - Электрон. текстовые дан. - Красноярск: НИЦ, 2021. - 112 с. - Режим доступа: http://nkras.ru/arhiv/2021/SkripnikovaGV.pdf - Систем. требования: IBM PC; Internet Explorer и др.; Acrobat Reader 3.0 или старше.

\section{ISBN 978-5-907208-58-2 \\ DOI: 10.12731/978-5-907208-58-2}

Учебное пособие разработано по дисииплине «Физическая культура». Пособие содержит теоретические сведения в области физической культуры и спорта, практические задания, которые помогут студентам сформировать систему знаний по основам физического воспитания, профессионально-прикладной физической подготовки, здоровому образу жизни, организачии самостоятельных занятий и др., которая позволит им в будущей профессиональной деятельности правильно использовать средства физической культуры и спорта. Предназначается обучаюшимся дневной формы обучения всех специальностей БИФ КемГУ.

\section{Свидетельство о регистраиии}

электронного издания сетевого распространения № 2047, зарегистрировано ФГУП НТЦ «Информрегистр» «16» марта 2021 г. и ему присвоен номер регистрации 0522100168.

ISBN 978-5-907208-58-2

(C) Кемеровский государственный университет, 2021

(C) Скрипникова Г.В., 2021

(c) Оформление. Научно-инновационный центр, 2021 
СОДЕРЖАНИЕ

Введение 4

Раздел 1. Курс лекций «Теория экономического анализа» 5

Раздел 2. Практикум

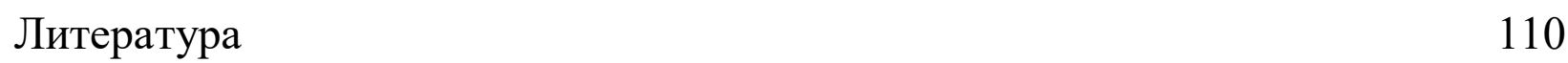




\section{Введение}

Целью данного учебного пособия является формирование у студентов аналитического мышления на основе применения методологических основ и приобретения навыков самостоятельной работы с нормативно-правовой документацией в области экономического анализа.

В процессе изучения дисциплины студенты должны изучить основные направления анализа, его виды и методы, научиться понимать сущность экономических процессов, их взаимосвязь, уметь проводить анализ, определять влияния различных факторов, оценивать достигнутые результаты, объединять полученные данные, выявлять и предлагать различные методы, резервы и рекомендации повышения эффективного функционирования предприятия, а так же давать оценку и анализ дальнейшего развития предприятия в будущем. В данном пособии раскрыты ключевые темы дисциплины «Экономический анализ».

Учебное пособие предназначено для студентов всех форм обучения экономических направлений. При изложении материала автор исходил из того, что некоторые вопросы не нуждаются в раскрытии или дополнительном разъяснении, так как изучающие предмет должны быть знакомы с организацией, управлением, планированием деятельности предприятия, статистикой, основами бухгалтерского учета.

При формировании тех или иных разделов автор исходил из логики изучения дисциплины и практики проведения занятий по экономическому анализу.

Экономический анализ является научной базой принятия управленческих решений в бизнесе. Для их обоснования необходимо выявлять и прогнозировать существующие и потенциальные проблемы, производственные и финансовые риски, определять воздействия принимаемых решений на уровень рисков и доходов субъекта хозяйствования. 


\section{Раздел 1.}

\section{Курс лекций «Теория экономического анализа»}

\section{$\underline{\text { Tема } 1}$}

\section{Понятие и значение экономического анализа}

1. Понятие об анализе хозяйственной деятельности.

2. Виды экономического анализа.

3. Роль анализа в управлении производством.

\section{1. Понятие об анализе хозяйственной деятельности.}

Изучение явлений природы и общественной жизни невозможно без анализа. Сам термин «анализ» происходит от греческого слова «analyzis» «разделяю», «расчленяю». Следовательно, анализ в узком плане представляет собой расчленение явления (предмета) на составные его части (элементы) для изучения их как частей целого. Такое расчленение позволяет заглянуть вовнутрь исследуемого предмета, явления, процесса, понять его внутреннюю сущность, определить роль каждого элемента в изучаемом предмете или явлении.

Например, чтобы понять сущность себестоимости продукции, необходимо знать не только из каких элементов она состоит, но и от чего зависит ее величина по каждой статье затрат. Чем детальнее будет разложен прирост себестоимости по элементам и факторам, тем больше мы будем знать об этом экономическом явлении и более эффективно управлять процессом формирования себестоимости продукции.

В науке и на практике применяются разные виды анализа: физический, химический, математический, статистический, экономический и др. Они отличаются объектами, целями и методикой исследования. Экономический анализ в отличие от других видов анализа относится к абстрактно-логическому методу исследования.

Сегодня нужно отличать общетеоретический экономический анализ, который изучает экономические явления и процессы на макроуровне (на 
государственном уровне национальной экономики и еe отдельных отраслей), и конкретно - экономический анализ на микроуровне - АХД, который применяется для изучения экономики отдельный предприятий.

Становление АХД как науки было обусловлено общими объективными требованиями и условиями, которые свойственны возникновению новой отрасли знаний.

Во-первых, это удовлетворение практической потребности. Она возникла в связи с развитием производственных сил, совершенствованием производственных отношений, расширением масштабов производства. Без комплексного всестороннего АХД невозможно управлять сложными экономическими процессами, принимать оптимальные решения.

Во-вторых, это связано с развитием экономической науки в целом. Экономический анализ хозяйственной деятельности сформировался в результате дифференциации общественных наук. Раньше функции экономического анализа рассматривались в рамках существовавших в то время таких научных дисциплин, как балансоведение, бухучет, финансы, статистика. В рамках этих наук появились первые простейшие способы аналитического исследования. Однако для обоснования текущих и пятилетних планов экономического и социального развития предприятия появилась потребность в комплексном всестороннем исследовании деятельности предприятия. Вышеназванные науки уже не могли обеспечить все запросы практики. Возникла необходимость выделения АХД в самостоятельную отрасль знаний. В дальнейшем роль экономического анализа возрастала соответственно цене ошибки в хозяйственной деятельности. Анализ стал важным средством планового управления экономикой предприятия, выявления резервов повышения эффективности производства.

Современное состояние анализа можно охарактеризовать как основательно разработанную, в теоретическом плане, науку. Ряд методик, 
созданных научными работниками, используются в управлении производством на разных уровнях. Вместе с тем наука находится в состоянии развития. Ведутся исследования в области более широкого применения математических методов, ЭВМ. Позволяющих оптимизировать управленческие решения. Идет процесс внедрения теоретических достижений отечественной и зарубежной науки в практику.

Перспективы развития АХД в теоретическом направлении тесно связаны с развитием смежных наук, в первую очередь математики, статистики, бухучета и др. Кроме того, развитие анализа зависит и от запросов практики.

Что касается перспектив прикладного характера, то АХД постепенно займет ведущее место в системе управления. Этому содействуют преобразования, которые происходят в нашем обществе. Совершенствование экономического механизма через переход к рынку, конкуренция предприятий и форм собственности будут содействовать повышению заинтересованности в этой науке.

\section{2. Виды экономического анализа.}

Классификация АХД имеет важное значение для правильного понимания его содержания и задач.

В экономической литературе АХД классифицируется по различным признакам.

\section{Классификаиия:}

I. По отраслевому признаку, который основывается на общественном разделении труда анализ делится на:

- отраслевой, методика которого учитывает специфику отдельных отраслей экономики (с/х, торговля, промышленность и др.);

- межотраслевой, который является теоретической и методологической основой АХД во всех отраслях национальной экономики (теория экономического анализа). 


\section{II. По признаку времени анализ делится на:}

- предварительный (перспективный) проводится до осуществления хозяйственных операций. Он необходим для обоснования управленческих решений и плановых заданий, а также для прогнозирования будущего и оценки ожидаемого выполнения плана, предупреждения нежелательных результатов;

- последующий (ретроспективный) анализ проводится после совершения хозяйственных актов. Он используется для контроля за выполнением плана, выявления неиспользованных резервов, объективной оценки результатов деятельности предприятия.

Перспективный и ретроспективный анализы тесно связаны между собой. Без ретроспективного анализа невозможно сделать перспективный. Анализ результатов труда за прошлые годы позволяет изучить тенденции. Закономерности, выявить неиспользованные возможности, передовой опыт и т.д., что имеет важное значение при обосновании уровня экономических показателей на перспективу.

В свою очередь от глубины и качества предварительного анализа на перспективу зависят результаты ретроспективного анализа. Если плановые показатели недостаточно обоснованы и реальны, то последующий анализ выполнения плана теряет смысл и требует предварительной оценки обоснованности плановых показателей.

Ретроспективный анализ в свою очередь делится на:

- оперативный (ситуационный) анализ - проводится сразу после совершения хозяйственных операций или изменения ситуации за короткие отрезки времени (смену, сутки, декаду и т.д.). Цель анализа - оперативно выявить недостатки и воздействовать на хозяйственные процессы;

- итоговый (заключительный) анализ - проводится за отчетный период времени (месяц, квартал, год). Его ценность в том, что деятельность предприятия изучается комплексно и всесторонне по 
отчетным данным за соответствующий период. Этим обеспечивается более полная оценка деятельности предприятия по использованию имеющихся возможностей.

III. По пространственному признаку анализ делится на:

- внутрихозяйственный анализ - изучает деятельность только исследуемого предприятия и его структурных подразделений;

- межхозяйственный анализ, когда сравниваются результаты деятельности двух и более предприятий. Это позволяет выявить передовой опыт, резервы, недостатки и на основе этого дать более объективную оценку эффективности деятельности предприятия.

IV. По объектам управления анализ делится на:

- технико-экономический, которым занимаются технические службы предприятия. Его содержанием является изучение взаимодействия технических и экономических процессов и установление их влияния на экономические результаты деятельности предприятия;

- финансово-экономический, уделяет особое внимание финансовым результатам деятельности предприятия: выполнению плана, эффективности использования собственного и заемного капитала, выявлению резервов увеличения суммы прибыли, улучшению финансового состояния;

- аудиторский (бухгалтерский) анализ - это экспертная оценка финансового «здоровья» предприятия. Проводится аудиторами с целью прогнозирования финансового состояния и финансовой устойчивости субъектов хозяйствования;

- социально-экономический анализ изучает взаимосвязь социальных и экономических процессов, их влияние друг на друга и на экономические результаты хозяйственной деятельности;

- экономико-статистический анализ применяется для изучения массовых общественных явлений на разных уровнях управления; 
- экономико-экологический анализ исследует взаимодействие экологических и экономических процессов, связанных с сохранением и улучшением окружающей среды и затратами на экологию;

- маркетинговый анализ применяется для изучения внешней среды функционирования предприятия, рынков сбыта, спроса и предложения, формирования ценовой политики.

V. По методике изучения объектов АХД может быть сравнительным, диагностическим, факторным, функциональностоимостным и т.д.

- факторный анализ направлен на выявление величины влияния факторов на прирост и уровень результативных показателей;

- диагностический (экспресс-анализ) представляет собой способ установления характера нарушений нормального хода экономических процессов на основе типичных признаков, характерных только для данного нарушения. Например, темпы роста валовой продукции опережают темпы роста товарной продукции, то это свидетельствует о росте остатков незавершенного производства;

- маржинальный анализ - это метод оценки и обоснования эффективности управленческих решений в бизнесе на основании причинно-следственной взаимосвязи объема продаж, себестоимости, прибыли и деления затрат на постоянные и переменные;

- экономико-математический анализ выбирает наиболее оптимальный вариант решения экономической задачи, выявляются резервы повышения эффективности производства за счет более полного использования имеющихся резервов;

- функционально-стоимостной анализ представляет собой метод выявления резервов. Его основное назначение в том, чтобы выявить и предупредить лишние затраты за счет ликвидации ненужных узлов, деталей, замены материалов и т.д. 
VI. По субъектам анализа различают:

- внутренний анализ - проводится непосредственно на предприятии для нужд оперативного, краткосрочного и долгосрочного управления производственной, коммерческой и финансовой деятельностью.

- внешний - проводится на основании финансовой и статистической отчетности органами хозяйственного управления, банками, акционерами, инвесторами.

VII. По охвату изучаемых объектов анализ делится на:

- сплошной, выводы делаются после изучения всех без исключения объектов;

- выборочный, выводы делаются по результатам обследования только части объектов.

VIII. По содержанию программы анализ может быть:

- комплексный, деятельность предприятия изучается всесторонне;

-тематический, изучаются только отдельные ее стороны, представляющие в определенный момент наибольший интерес.

Каждая из названных форм АХД своеобразна по содержанию, организации и методике его проведения.

3. Роль анализа в управлении производством. В настоящее время АХД занимает важное место среди экономических наук. Его рассматривают в качестве одной из функций управления производством.

Планирование представляет собой очень важную функцию в системе управления производством на предприятии. С его помощью определяются направление и содержание деятельности предприятия, его структурных подразделений и отдельных работников. Главной задачей планирования является обеспечение планомерности развития экономики предприятия и деятельности каждого его члена, определение путей достижения лучших конечных результатов производства. 
Для управления производством нужно иметь полную и правдивую информацию о ходе производственного процесса, о ходе выполнения планов. Поэтому одной из функций управления производством является учет. Он обеспечивает постоянный сбор, систематизацию и обобщение данных, необходимых для управления производством и контроля за ходом выполнения планов и производственных процессов.

Кроме этого для управления производством необходимо иметь представление о тенденциях и характере происходящих изменений в экономике предприятия. Осмысление, понимание информации достигается с помощью экономического анализа. В процессе анализа первичная информация проходит аналитическую обработку: проводится сравнение достигнутых результатов производства с данными за прошлые отрезки времени, с показателями других предприятий, определяется влияние разных факторов на величину результативных показателей, выявляются недостатки, ошибки, неиспользованные возможности, перспективы и т.д.

На основе результатов анализа разрабатываются и обосновываются управленческие решения. Экономический анализ предшествует решениям и действиям, обосновывает их и является основой научного управления производством, обеспечивает его объективность и эффективность. Таким образом, экономический анализ - это функиия управления, которая обеспечивает научность принятия решений.

Как функция управления АХД тесно связан с планированием и прогнозированием производства, поскольку без глубокого анализа невозможно осуществление этих функций. Важна роль АХД в подготовке информации для планирования, оценки качества и обоснованности плановых показателей, в проверке и объективной оценке выполнения планов.

Большая роль отводится анализу в деле определения и использования резервов повышения эффективности производства. Он 
содействует экономному использованию ресурсов, выявлению и внедрению передового опыта, научной организации труда, новой техники и технологии производства и т.д. В результате этого укрепляется экономика предприятия, повышается эффективность производства.

Таким образом, АХД является важным элементом в системе управления производством, действенным средством выявления внутрихозяйственных резервов, основой разработки научно обоснованных планов и управленческих решений.

Роль анализа как средства управления производством с каждым годом возрастает. Это обусловлено разными обстоятельствами. Во-первых, необходимостью неуклонного повышения эффективности производства в связи с ростом дефицита и стоимости сырья, повышением науко- и капиталоемкости производства. Во-вторых, переходом к рыночным отношениям. В-третьих, созданием новых форм хозяйствования в связи с разгосударствлением экономики, приватизацией предприятий и прочими мероприятиями экономической реформы.

\section{Tема 2}

\section{Предмет, содержание и задачи АХД}

1. Предмет и объекты АХД.

2. Содержание и задачи АХД.

3. Принципы АХД.

4. Связь АХД с другими науками.

\section{1. Предмет и объекты АХД.}

Каждая наука имеет свой предмет исследования, который она изучает с соответствующей целью присущими ей методами.

Философия под предметом любой науки понимает какую-то часть или сторону объективной действительности, которая изучается только 
данной наукой.

Предметом той или иной науки следует считать то специфическое, что позволяет отличить ее среди множества других наук.

Все определения предмета АХД можно сгруппировать следующим образом: а) хозяйственная деятельность предприятия; б) хозяйственные процессы и явления.

При более внимательном рассмотрении этих определений можно заметить, что анализ изучает не саму хозяйственную деятельность как технологический, организационный процесс, а экономические результаты хозяйствования. Поэтому в последнее время большинство исследователей, предметом АХД считают экономические процессы, которые происходят в результате хозяйственной деятельности. Однако, экономические процессы деятельности предприятия являются объектом изучения многих наук.

Чтобы выделить ту часть или те отношения в этом объекте, которые относятся только к анализу, нужно исходить из сущности процессов хозяйственной деятельности. Процесс - это причинно-обусловленное течение событий, смена явлений, состояния объекта в соответствии с намеченной целью или результатом. Но результаты как следствия процессов являются не предметом АХД, а объектами. Предметом же экономического анализа являются причины образования и изменения результатов хозяйственной деятельности.

Познание причинно-следственных связей деятельности предприятия позволяет раскрыть сущность экономических явлений и на этой основе дать правильную оценку достигнутым результатам. Выявить резервы повышения эффективности производства, обосновать планы и управленческие решения.

Таким образом, предметом АХД являются причинно-следственные связи экономических явлений и прочессов.

Объектами АХД являются экономические результаты хозяйственной 
деятельности. Например, на промышленном предприятии к объектам АХД относятся производство и реализация продукции, ее себестоимость, использование материальных, трудовых и финансовых ресурсов, финансовые результаты производства и т.д.

Таким образом, мы рассмотрели предмет и объекты АХД. Основное отличие предмета от объекта заключается в том, что в предмет входят лишь главные, наиболее существенные, с точки зрения данной науки, свойства и признаки.

\section{2. Содержание и задачи АХД.}

Содержание АХД как науки вытекает прежде всего из функций, которые она выполняет в системе других прикладных наук. $\underline{\text { Oдной из }}$ таких функиий является изучение характера действия экономических законов, установление закономерностей и тендениий экономических явлений и прочессов в конкретных условиях предприятия.

Например, закон опережающего роста производительности труда в сравнении с уровнем его оплаты должен выполняться не только в масштабах всей экономики, но и на каждом предприятии и его подразделениях. В этой своей функции АХД является средством изучения действия экономических законов в конкретных условиях производства.

Важной функцией АХД является научное обоснование текущих и nерспективных планов. Без глубокого анализа результатов деятельности предприятия за прошлые годы (5-10 лет) и без обоснованных прогнозов на перспективу, без изучения закономерностей развития экономики предприятия нельзя разработать научно обоснованный план, выбрать оптимальный вариант управленческого решения.

К функциям анализа относится также контроль за выполнением планов и управленческих решений, за экономным использованием ресурсов. Анализ проводится не только с целью констатации фактов и оценки достигнутых результатов, но и с целью выявления недостатков, ошибок и 
оперативного воздействия на процесс производства. Именно поэтому необходимо повышать оперативность и действенность анализа.

Центральная функция анализа, которую выполняет на предприятии поиск резервов повышения эффективности производства на основе изучения передового опыта и достижений науки и техники.

Следующая функция анализа - оценка результатов деятельности предприятия по выполнению планов, достигнутому уровню развития экономики, использованию имеющихся возможностей.

И наконец, разработка мероприятий по использованию вылявленных резервов в процессе хозяйственной деятельности - также одна их функций АХД.

Таким образом, АХД как наука представляет собой систему специальных знаний, связанных с исследованиями тенденций хозяйственного развития, научным обоснование планов, управленческих решений. Контролем за их выполнением, оценкой достигнутых результатов, поиском, измерением и обоснованием величины хозяйственных резервов повышения эффективности производства и разработкой мероприятий по их использованию.

\section{3. Принципы АХД.}

Аналитическое исследование, его результаты и их использование в управлении производством должны соответствовать определенным требованиям.

1. Анализ должен базироваться на государственном подходе при оценке экономических явлений, процессов, результатов хозяйствования. T.e., оценивая определенные проявления экономической жизни, нужно учитывать их соответствие государственной экономической, социальной, международной политике и законодательству.

2. Анализ должен носить научный характер, т.е. учитывать требования экономических законов развития производства, использовать 
достижения НТП и передового опыта, новейшие методы экономических исследований.

3. Анализ должен быть комплексным, т.е. охват все звеньев и всех сторон деятельности и всестороннего изучения причинных зависимостей в экономике предприятия.

4. Обеспечение системного подхода, когда изучаемый объект рассматривается как сложная динамическая система, состоящая из ряда элементов, определенным способом связанных между собой и внешней средой.

5. Анализ должен быть объективным. Конкретным и точным. Он должен базироваться на достоверной, проверенной информации, реально отражающей объективную действительность, а выводы его должны обосновываться точными аналитическими расчетами.

6. Анализ должен быть действенным, активно воздействовать на ход производства и его результаты, своевременно выявляя недостатки, просчеты, упущения в работе и информируя об этом руководство предприятия.

7. Анализ должен проводиться по плану, систематически, а не от случая к случаю.

8. Анализ должен быть оперативным, что означает умение быстро и четко производить анализ, принимать управленческие решения и претворять их в жизнь.

9. Демократизм, т.е. участие в проведении анализа широкого круга работников предприятия, что обеспечивает более полное выявление передового опыта и использование имеющихся внутрихозяйственных резервов.

10. Анализ должен быть эффективным, т.е. затраты на его проведение должны давать многократный эффект.

Таким образом, основными принципами анализа являются 
научность, комплексность, системность, объективность, точность, достоверность, действенность, оперативность, демократизм, эффективность. Ими следует руководствоваться при проведении АХД на любом уровне.

\section{4. Связь АХД с другими науками.}

В первую очередь среди наук, с которыми связан АХД, нужно выделить экономическую теорию, которая, изучая экономические законы, механизм их действия, создает основу для развития всех экономических дисциплин. При проведении аналитических исследований необходимо учитывать действия этих законов. В свою очередь АХД определенным образом содействует развитию экономической теории.

Экономический анализ также тесно связан с отраслевыми экономиками. Глубокий анализ хозяйственной деятельности предприятия не возможно провести, не зная экономики отрасли и организации производства на анализируемом предприятии. В свою очередь результаты экономического анализа используются для совершенствования организации производства, внедрения научной организации труда, передового опыта и т.д. анализ содействует подъему экономики конкретных предприятий и отрасли в целом.

(Связь с планированием и управлением производством, бухучетом, финансированием и кредитование, статистикой и др. самостоятельно!!)

Таким образом, АХД является наукой, которая сформировалась путем интеграции целого ряда наук и объединила отдельные их элементы. В свою очередь результаты анализа используются другими науками при изучении тех или иных сторон хозяйственной деятельности.

\section{Tема 3}

\section{Метод и методика комплексного экономического АХД} предприятий. 
1. Метод АХД, его характерные черты.

2. Системный подход в АХД.

3. Методика комплексного АХД.

4. Разработка системы взаимосвязанных аналитических показателей.

\section{1. Метод АХД, его характерные черты.}

Под методом науки в широком смысле понимают способ исследования своего предмета. Специфические для различных наук способы подхода к изучению своего предмета базируются на всеобщем диалектическом методе познания, то есть все явления и процессы необходимо рассматривать в постоянном движении, изменении, развитии. $\underline{\text { Здесь исток одной из характерных черт метода АХД - необходимость }}$ nостоянных сравнений. Фактические результаты деятельности сравниваются с результатами прошлых лет, достижениями других предприятий, плановыми показателями и т.д.

Материалистическая диалектика учит, что каждый процесс надо рассматривать как единство и борьбу противоположностей. Отсюда вытекает необходимость изучения внутренних противоречий, положительных и отрицательных сторон каждого явления, каждого nроцесса. Это тоже одна из характерных черт АХД. Например, НТП положительно влияет на производительность труда, повышение уровня рентабельности, при этом надо учитывать и отрицательные черты, такие как загрязнение окружающей среды и др.

Использование диалектического метода в анализе означает, что изучение хозяйственной деятельности предприятия должно проводиться с учетом всех взаимосвязей. Ни одно явление не может быть правильно понято, если оно рассматривается без связи с другим.

Важной чертой анализа является и то, что он способен давать 
количественную характеристику причинно- следственным связям, т.е. обеспечивать измерение влияния факторов на результаты деятельности.

Изучение и измерение причинных связей в анализе можно осуществить методом индукции и дедукции. Способ исследования причинных связей с помощью логической индукции заключается в том, что исследование ведется от частного к общему, от причин к результатам. Дедукция - это такой способ, когда исследование осуществляется от общих факторов к частным, от результатов к причинам.

Использование диалектического метода в АХД означает, что каждый процесс, каждое явление надо рассматривать как систему, как совокупность многих элементов, связанных между собой. Из этого вытекает необходимость системного подхода к изучению объектов анализа, что является еще одной его характерной чертой.

Системный подход предусматривает максимальную детализацию изучаемых явлений и процессов на элементы (собственно анализ), их систематизацию и синтез. Детализация необходима для выяснения наиболее существенного и главного в изучаемом объекте. Она зависит от объекта и цели анализа.

Систематизация элементов проводится на основе изучения их взаимосвязи, взаимодействия и взаимозависимости. Это позволяет построить приблизительную модель изучаемого объекта, определить его главные компоненты, функции, соподчиненность элементов системы, раскрыть схему анализа, которая соответствует внутренним связям изучаемых показателей.

После изучения отдельных сторон экономики предприятия, их взаимосвязи, подчиненности и зависимости надо обобщить весь материал исследования. Обобщение (синтез) является очень ответственным моментом в анализе. При обобщении результатов анализа необходимо из всего множества изучаемых факторов отделить типичные от случайных, 
выделить главные и решающие, от которых в основном зависят результаты деятельности.

Важной методологической чертой АХД является разработка $u$ использование системы показателей, необходимой для комплексного, системного исследования причинно-следственных связей экономических явлений и процессов в хозяйственной деятельности предприятия.

Таким образом, метод АХД представляет системное, комплексное изучение, измерение и обобщение влияния факторов на результатьи деятельности предприятия путем обработки специальньми приемами системы показателей плана, учета, отчетности и других источников информации с иелью повьиения эффрективности производства.

\section{2. Системный подход в АХД.}

Системный подход - это направление в методологии исследования. Он базируется на изучении объектов как сложных систем, которые состоят из отдельных элементов с многочисленными внутренними и внешними связями.

Главные особенности системного подхода - динамичность, взаимодействие, взаимозависимость и взаимосвязь элементов системь, комплексность, иелостность, соподчиненность, выделение ведущего звена.

Системный подход в экономическом анализе позволяет разработать научное обоснованные варианты решения хозяйственных задач, определить эффективность этих вариантов, что дает основание для выбора наиболее целесообразных управленческих решений.

\section{Этапы системного подхода:}

I. Объект анализа представляется как определенная система. Для этого сначала выделяют отдельные части объекта, которые могут рассматриваться как элементы системы. Кроме того, на первом этапе анализа должна быть сформулирована цель развития системы, задачи, 
которые она решает, связь с другими системами.

II. Подбор показателей, которые способны дать наиболее полную и качественную оценку всем без исключения элементам, взаимосвязям, а также условиям, в которых существует система.

III. Разработка общей схемы изучаемой системы. Графически она обычно представляется в виде блочного рисунка, где каждому элементу соответствует определенный блок. Отдельные блоки связаны между собой стрелками, которые показывают наличие и направление внутренних и внешних связей системы.

IV. Построение в общем виде экономико-математической модели системы. При этом на основе качественного анализа определяются математические формы всех уравнений и неравенств системы. На этом этапе должны быть определены коэффициенты всех уровней и неравенств, функции цели и параметры ограничений.

V. «Работа с моделью». Путем замены отдельных параметров ЭММ, которые характеризуют те или другие факторы производства, определяют значение функции. Сравнение этих показателей с фактическими, плановыми и другими позволит оценить итоги хозяйствования, влияния факторов на величину результативных показателей, определить источники и объемы неиспользованных резервов.

Описанный подход к анализу имеет существенные преимущества по сравнению с другими: он обеспечивает комплексность и целенаправленность исследований, объективную оценку результатов хозяйствования, оперативность точность анализа и его выводов.

3. Методика комплексного АХД. Использование метода АХД проявляется через ряд конкретных методик аналитического исследования. Надо отметить, что каждому виду анализа соответствует своя методика.

Под методикой понимается совокупность способов, правил наиболее целесообразного выполнения какой-либо работы. В 
экономическом анализе методика представляет собой совокупность аналитических способов и правил исследования экономики предприятия, определенным образом подчиненных достижению цели анализа. Общую методику понимают как тему исследования, которая одинаково используется при изучении различных объектов экономического анализа в различных отраслях национальной экономики. Частные методики конкретизируют общую относительно к определенным отраслям экономики, к определенному типу производства или объекту исследования.

При выполнении комплексного АХД выделяются следующие этапы:

I. У Уочняются объекты, цель и задачи анализа.

II. Разрабатывается система синтетических и аналитических показателей, с помощью которых характеризуется объект анализа.

III. Собирается и подготавливается к анализу необходимая информация.

IV. Сравнение фактических результатов хозяйствования с показателями плана отчетного года, фактическими данными прошлых лет, с достижениями ведущих предприятий и т.д.

V. Выполняется факторный анализ.

VI. Выявляются неиспользованные и перспективные резервы повышения эффективности производства.

VII. Оценка результатов хозяйствования с учетом действия различных факторов и выявленных неиспользованных резервов, разрабатываются мероприятия по их использованию.

В качестве важнейшего элемента методики АХД выступают технические приемы и способы анализа. Они используются для:

a) первичной обработки собранной информации;

б) изучения состояния и закономерностей развития исследуемых объектов; 
в) определения влияния факторов на результаты деятельности предприятия;

г) обобщения результатов анализа и комплексной оценки деятельности предприятия;

д) обоснования планов экономического и социального развития, управленческих решений, различных мероприятий.

В экономическом анализе используется много различных способов.
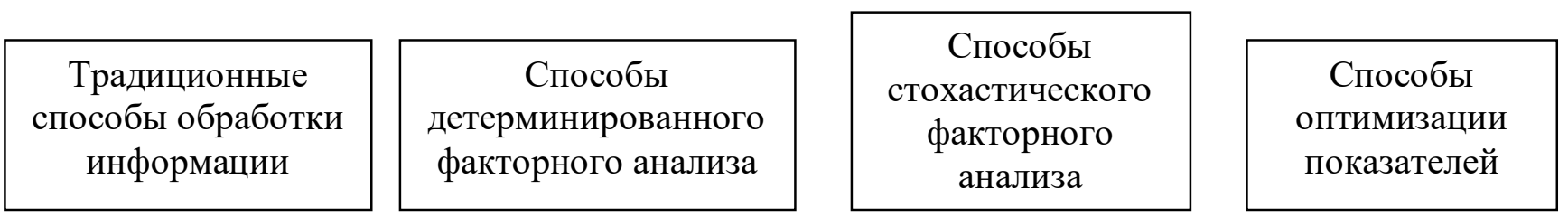

Применение тех или иных способов зависит от цели и глубины анализа, объекта исследования, технических возможностей выполнения расчетов и т.д.

\section{4. Разработка системы взаимосвязанных аналитических} показателей. Все объекты АХД находят свое отображение в системе показателей плана, учета, отчетности и других источниках информации. Каждое экономическое явление (процесс) чаще определяется не одним, а целым комплексом взаимосвязанных показателей. Например, эффективность использования основных средств производства характеризуют уровень фондоотдачи, фондоёмкости, рентабельности и т.д. От того, насколько показатели полно и точно отражают сущность изучаемых явлений, зависят результаты анализа.

Так как в анализе используется большое количество разнокачественных показателей, необходима их группировка и систематизация.

Классификация показателей:

I. По содержанию показатели делятся на:

- количественные (объем изготовленной продукции, количество 
работников и т.д.);

- качественные (производительность труда, себестоимость, рентабельность и др.).

II. По степени детализации:

- общие (производительность труда, прибыль, себестоимость и др.) используются для АХД всех отраслей национальной экономики;

- специфические (калорийность каменного угля, урожайность культур и др.) используются при анализе деятельности в отдельных отраслях.

III. По степени синтеза:

- обобщающие применяются для обобщающей характеристики сложных экономических явлений (среднегодовая, среднедневная выработка продукции одним работником);

- частные отражают отдельные стороны, элементы изучаемых явлений (процессов) (затраты рабочего времени на производство единицы продукции определенного вида);

- вспомогательные (косвенные) используются для более полной характеристики того или иного объекта анализа (количество рабочего времени, затраченного на ед. выполненных работ).

IV. По характеру:

- абсолютные выражаются в денежных, натуральных измерителях или через трудоемкость;

а) натуральные выражают величину явления в физических измерителях (масса, длина, объем и т.д.);

б) стоимостные показывают величину сложных явлений в денежном измерении.

$\mathrm{V}$. При изучении причинно-следственных отношений показатели делятся на:

- факторные, которые определяют поведение результативного 
показателя и выступают в качестве причин изменения его величины;

- результативные, если показатель рассматривается как результат воздействия одной или нескольких причин и выступает в качестве объекта исследования.

VI. По способу формирования различают показатели:

- нормативные (нормы расхода сырья, материалов и др.);

- плановые (данные планов экономического и социального развития предприятия);

- учетные (данные бухгалтерского, оперативного и статистического учета);

- отчетные (данные бухгалтерской, оперативной и статистической отчетности);

- аналитические (оценочные), которые исчисляются в ходе самого анализа для оценки результатов и эффективности работы предприятия.

Комплексное изучение экономики предприятия предусматривает систематизацию показателей, потому что совокупность показателей без учета их взаимосвязи, соподчиненности, не может дать настоящего представления об эффективности хозяйственной деятельности.

Система показателей комплексного АХД.

Показатели организационно-технического уровня характеризуют производственную структуру предприятия, структуру управления, продолжительность производственного цикла, степень механизации и автоматизации и т.д.

Показатели приведенной подсистемы оказывают влияние на все остальные показатели хозяйственной деятельности и в первую очередь на объем производства и реализации продукции, ее качество, себестоимость, прибыль, рентабельность и т.д. Поэтому АХД надо начинать с изучения этой подсистемы.

Показатели второй подсистемь характеризуют обеспеченность 
предприятия основными средствами производства, оборудованием материалами и трудовыми ресурсами. От того, насколько полно и своевременно обеспечивается производство всеми необходимыми средствами, зависит выход продукции, себестоимость, финансовое положение предприятия.

Tретий блок включает показатели производства продукции: объем валовой и товарной продукции в стоимостном, натуральном и условнонатуральном измерении, структуру продукции, ритмичность производства и др.

K показателям четвертого блока относятся данные об объеме отгрузки и реализации продукции, остатках готовой продукции на складах.

Основными показателями подсистемы 5 являются фондоотдача, фондоёмкость, среднегодовая стоимость основных средств производства, амортизация. Они связаны с показателями 3 и 9 блоков.

В подсистеме 6 основными показателями являются материалоёмкость, материалоотдача, стоимость использованных предметов труда за анализируемый отрезок времени. Они тесно связаны с показателями подсистем 7, 8, 9, 10. От экономного использования материалов зависит выход продукции, себестоимость, а значит и сумма прибыли, уровень рентабельности, ФСП.

K nодсистеме 10 относятся показатели, которые характеризуют наличие и структуру капитала предприятия по составу его источников и формам размещения, эффективность и интенсивность использования собственных и заемных средств. Отношения с финансовыми органами и т.д. К этой подсистеме относятся также показатели, которые характеризуют использование прибыли, фондов накопления и потребления, платежеспособность предприятия, его финансовую устойчивость.

Таким образом, все показатели хозяйственной деятельности 
предприятия находятся в тесной связи и зависимости, которую необходимо учитывать в комплексном анализе.

\section{$\underline{\text { Teмa } 4}$}

Способы обработки экономической информации в АХД предприятия

1.Способы сравнения в АХД.

2.Многомерные сравнения в АХД.

3. Способы приведения показателей в сопоставимый вид.

4.Способы использования относительных и средних величин в АХД.

5.Способы группировки информации в АХД.

6.Балансовый способ в АХД.

7.Использование графического способа в АХД.

1. Способы сравнения в АХД. Сравнение - один из способов, с помощью которых человек начал распознавать окружающую среду. Широкое распространение он получил и в исследовании экономических явлений. Каждый показатель, каждая цифра, используемая для оценки, контроля и прогноза, имеет значение только в сопоставлении с другой.

Сущность этого способа может быть раскрыта следующим образом.

Сравнение - это научный метод познания, в процессе его неизвестное (изучаемое) явления, предметы сопоставляются уже с известными, изучаемыми ранее, с целью определения общих черт либо различий между ними. С помощью сравнения определяется общее и специфическое в экономических явлениях, изучаются изменения исследуемых объектов, тенденции и закономерности их развития. В экономическом анализе сравнения используют для решения всех задач. 
Перечислим наиболее типичные ситуации, когда используется сравнение, и цели, которые при этом достигаются.

1. Сопоставление плановых и фактических показателей для оценки степени выполнения плана.

2. Сопоставление фактических показателей с нормативными, что позволяет провести контроль за затратами и способствует внедрению ресурсосберегающих технологий.

3. Сравнение фактических показателей с показателями прошлых лет для определения тенденций развития экономических процессов.

4. Сопоставление показателей анализируемого предприятия с достижениями науки и передового опыта других предприятий (подразделений) необходимо для поиска резервов.

5. Сопоставление показателей анализируемого хозяйства со средними показателями по району, зоне, области для оценки достигнутых результатов и определения неиспользованных резервов.

6. Сопоставление параллельных и динамичных рядов для изучения взаимосвязей исследуемых показателей. Например, анализируя одновременно динамику изменения объема производства валовой продукции, ОПФ и фондоотдачи, можно обосновать взаимосвязь между этими показателями.

7. Сопоставление различных вариантов управленческих решений с целью выбора наиболее оптимального из них.

8. Сопоставление результатов деятельности до и после изменения какого-либо фактора применяется при расчете влияния факторов и подсчете резервов.

Рассмотрим более подробно каждый тип сравнения.

1. Выполнение плана по производству продукции

\begin{tabular}{|c|c|c|c|c|}
\hline \multirow[t]{2}{*}{$\begin{array}{l}\text { Вид } \\
\text { продукции }\end{array}$} & $\begin{array}{l}\text { Объе } \\
\text { проду }\end{array}$ & оизводства & \multirow[t]{2}{*}{$\begin{array}{c}\text { Абсолютное } \\
\text { отклонение от плана }\end{array}$} & \multirow[t]{2}{*}{$\begin{array}{l}\text { Выполнение } \\
\text { плана, \% }\end{array}$} \\
\hline & План & Факт & & \\
\hline
\end{tabular}




\begin{tabular}{|l|l|l|l|l|}
\hline А & 300 & 327 & +27 & 109 \\
\hline Б & 250 & 225 & -25 & 90 \\
\hline В & 500 & 510 & +10 & 102 \\
\hline И т.д. & $\ldots$ & $\ldots$ & $\ldots$ & $\ldots$ \\
\hline Всего & 4000 & 4200 & +200 & 105 \\
\hline
\end{tabular}

Вывод: из данных таблицы видно, что план производства по всем видам продукции перевыполнен на 5 \%.

2. Использование сырья и материалов

3.

\begin{tabular}{|c|c|c|c|c|}
\hline \multirow{2}{*}{$\begin{array}{l}\text { Вид } \\
\text { материальных } \\
\text { ресурсов }\end{array}$} & \multicolumn{2}{|l|}{ Расход ресурсов, т. } & \multicolumn{2}{|c|}{$\begin{array}{l}\text { Отклонение от норматива (+/- } \\
\text { ) }\end{array}$} \\
\hline & $\begin{array}{l}\text { По норме на } \\
\text { факт. объем } \\
\text { продукции } \\
\end{array}$ & фактически & $\begin{array}{l}\text { Абсолютное, } \\
\text { т }\end{array}$ & $\begin{array}{l}\text { Относительное, } \\
\%\end{array}$ \\
\hline Нефтепродукты & 600 & 615 & +15 & $+2,5$ \\
\hline Сырье & 1200 & 1176 & -24 & $-2,0$ \\
\hline Материалы & 4650 & 4800 & +150 & $+3,2$ \\
\hline Топливо & 2500 & 2750 & +250 & $+10,0$ \\
\hline И т.д. & & & & \\
\hline
\end{tabular}

Вывод: из данных таблицы видно, что фактический расход ресурсов увеличился по сравнению с нормами по всем видам, кроме сырья, расход которого снизился на 24 т. (2\%).

3. Динамика основных показателей

\begin{tabular}{|l|l|l|l|l|l|l|}
\hline Ггод & \multicolumn{2}{|l|}{ Валовая продукция } & \multicolumn{2}{l|}{$\begin{array}{l}\text { Количество } \\
\text { работнков }\end{array}$} & $\begin{array}{l}\text { Производительность } \\
\text { труда }\end{array}$ \\
\cline { 2 - 7 } & $\begin{array}{l}\text { млн. } \\
\text { руб. }\end{array}$ & $\begin{array}{l}\text { \% к базисному } \\
\text { году }\end{array}$ & $\begin{array}{l}\text { Чел. } \\
\text { го базисному } \\
\text { году }\end{array}$ & $\begin{array}{l}\text { млн. } \\
\text { руб. }\end{array}$ & $\begin{array}{l}\text { \% к базисному } \\
\text { году }\end{array}$ \\
\hline 1991 & 3830 & 100,0 & 1094 & 100,0 & 3,5 & 100,0 \\
\hline 11992 & 3910 & 102,0 & 1087 & 99,3 & 3,6 & 102,8 \\
\hline 11993 & 4030 & 105,2 & 1075 & 98,2 & 3,75 & 107,1 \\
\hline 11994 & 4150 & 108,0 & 1064 & 97,2 & 3,90 & 111,4 \\
\hline 11995 & 4200 & 109,0 & 1000 & 91,4 & 4,20 & 120,0 \\
\hline
\end{tabular}

Вывод: из данных таблицы видно, что валовая продукция предприятия имеет тенденцию к увеличению. За пять лет объем производства продукции вырос на 9 \%, причем этот прирост обусловлен повышением производительности труда при уменьшении количества работников.

4. Сравнение с лучшими результатами может проводиться как в рамках исследования предприятия, так и за его пределами. Внутри 
предприятия проводится сравнение среднего уровня показателей достигнутых коллективом в целом, с показателями передовых участков, бригад, рабочих. Это позволяет выявить передовой опыт и новые возможности производства.

5. Сравнение показателей предприятия со среднеотраслевыми данными необходимо для более полной и объективной оценки деятельности анализируемого предприятия, для изучения общих и специфических факторов, определяющих результаты его деятельности.

6. Сравнение параллельных и динамических рядов используется для определения и обоснования формы и направления связи между разными показателями.

В экономическом анализе различают следующие виды сравнительного анализа: горизонтальный, вертикальный, трендовый, одномерный и многомерный.

Горизонтальный сравнительный анализ используется для определения абсолютных и относительных отклонений фактического уровня исследуемых показателей от базового (планового, прошлого периода, среднего уровня, достижений науки и передового опыта).

С помощью вертикального сравнительного анализа изучается структура экономических явлений и процессов путем расчета удельного веса в общем целом, соотношения частей целого между собой (например, собственного и заемного капитала), а также влияния факторов на уровень результативных показателей путем сравнения их величины до и после изменения соответствующего фактора.

Трендовый анализ применяется при изучении относительных темпов роста и прироста показателей за ряд лет к уровню базисного года, т.е. при исследовании рядов динамики.

При одномерном сравнительном анализе сопоставления делаются по одному или нескольким показателям одного объекта или нескольких 
объектов по одному показателю.

С помощью многомерного сравнительного анализа проводится сопоставление результатов деятельности нескольких предприятий по широкому спектру показателей.

2. Многомерные сравнения в АХД. Особое внимание заслуживают многомерные сравнения, которые необходимы в анализе для комплексной оценки результатов хозяйственной деятельности производственных подразделений, предприятий и т.д. Такая задача встает, когда необходимо дать обобщенную сравнительную оценку результатам хозяйствования нескольких предприятий.

Комплексная оценка хозяйственной деятельности представляет собой характеристику деятельности предприятий, полученную в результате изучения совокупности показателей, которые определяют большинство экономических процессов и содержат обобщающие данные о результатах производства. Чем больше показателей будет использовано для комплексной оценки, тем более правильными будут выводы анализа.

Задача комплексной оценки в территориальном плане сейчас решается в двух направлениях. Первое - это разработка обобщающего или интегрального показателя, который бы воплотил наиболее весомые стороны хозяйственной деятельности. Достижение этой цели привлекает тем, что в итоге ожидается получение единого показателя.

Другое направление комплексной оченки - разработка алгоритмов вычислительных процедур, которые бы на основе комплекса показателей обеспечили однозначную оценку результатов хозяйственной деятельности.

Наиболее перспективным подходом является использование методики многомерного сравнительного анализа, основанной на методике расстояний, которая позволяет учитывать не только абсолютные величины показателей каждого предприятия, но и степень их близости до показателей предприятия - эталона. 
Рассмотрим практическую сторону решения задачи многомерного сравнительного анализа.

Этап 1. Обосновывается система показателей, по которым будут оцениваться результаты хозяйственной деятельности предприятия, собираются данные по этим показателям, и формируется матрица исходных данных. Исходные данные могут быть представлены как в виде моментных показателей, отражающих состояние предприятия на определенную дату, так и темповых показателей, характеризующих динамику деятельности предприятий и представленных в виде коэффициентов роста. Возможно, изучение одновременно и моментных и темповых показателей.

\begin{tabular}{|c|c|c|c|c|c|c|c|}
\hline \multirow{2}{*}{$\begin{array}{l}\text { Ном } \\
\text { ep } \\
\Pi / \Pi\end{array}$} & \multirow[b]{2}{*}{$\begin{array}{l}\text { Запас } \\
\text { безубы } \\
\text { - } \\
\text { точнос } \\
\text { ти, } \\
\%\end{array}$} & \multicolumn{2}{|c|}{ Коэффициент } & \multicolumn{2}{|c|}{ Рентабельность } & \multirow{2}{*}{$\begin{array}{l}\text { Коэфф. ин. } \\
\text { независимо } \\
\text { сти }\end{array}$} & \multirow[b]{2}{*}{$\begin{array}{l}\text { Доля } \\
\text { собст. } \\
\text { оборотн } \\
\text { ого } \\
\text { капитала } \\
\text { в сумме } \\
\text { текущих } \\
\text { активов, } \\
\%\end{array}$} \\
\hline & & $\begin{array}{l}\text { Ликвидно } \\
\text { сти }\end{array}$ & $\begin{array}{l}\text { Оборачиваем } \\
\text { ости }\end{array}$ & $\begin{array}{l}\text { Прода } \\
\text { ж }\end{array}$ & $\begin{array}{l}\text { ККапит } \\
\text { ала }\end{array}$ & & \\
\hline 1 & 30 & 1,8 & 3,2 & 25 & 22 & 0,75 & 16 \\
\hline 2 & 25 & 2,0 & 2,5 & 30 & 26 & 0,62 & 26 \\
\hline 3 & 52 & 1,5 & 2,8 & 35 & 25 & 0,55 & 25 \\
\hline 4 & 40 & 1,7 & 2,2 & 33 & 38 & 0,68 & 30 \\
\hline 5 & 22 & 1,4 & 2,7 & 24 & 16 & 0,58 & 0 \\
\hline 6 & 30 & 1,6 & 3,5 & 20 & 21 & 0,72 & 35 \\
\hline
\end{tabular}

Этап 2. В каждой графе определяется максимальный элемент, который принимается за 1. Затем все элементы этой графы $\left(\mathrm{a}_{\mathrm{ij}}\right)$ делятся на максимальный элемент эталонного предприятия (max $\left.\mathrm{a}_{\mathrm{ij}}\right)$. В результате создается матрица стандартизированных коэффициентов $\left(\mathrm{x}_{\mathrm{ij}}\right)$.

\begin{tabular}{|c|c|c|c|c|c|c|c|}
\hline \multirow{2}{*}{$\begin{array}{l}\text { Номер } \\
\text { предприятия }\end{array}$} & \multicolumn{7}{|c|}{ показатели } \\
\hline & 1 & 2 & 3 & 4 & 5 & 6 & 7 \\
\hline 1 & 0,577 & 0,90 & 0,914 & 0,714 & 0,579 & 1 & 0,457 \\
\hline 2 & 0,481 & 1 & 0,714 & 0,857 & 0,684 & 0,826 & 0,743 \\
\hline 3 & 1 & 0,75 & 0,800 & 1 & 0,658 & 0,733 & 0,714 \\
\hline 4 & 0,769 & 0,85 & 0,628 & 0,943 & 1 & 0,907 & 0,857 \\
\hline 5 & 0,423 & 0,70 & 0,771 & 0,686 & 0,421 & 0,773 & 0 \\
\hline
\end{tabular}




\begin{tabular}{|l|l|l|l|l|l|l|l|}
\hline 6 & 0,577 & 0,80 & 1 & 0,571 & 0,553 & 0,960 & 1 \\
\hline
\end{tabular}

Этап 3. Все элементы матрицы координат возводятся в квадрат. Если задача решается с учетом разного веса показателей, тогда полученные квадраты умножаются на величину соответствующих весовых коэффициентов (К), установленных экспертным путем, после чего результаты складываются по строкам и из полученной суммы извлекается квадратный корень.

$$
R_{i}=\sqrt{K_{1} x_{1 j}^{2}+K_{2} x_{2 j}^{2}+\ldots+K_{n} x_{n j}^{2}}
$$

\begin{tabular}{|l|l|l|l|l|l|l|l|l|l|}
\hline \multirow{2}{*}{$\begin{array}{c}\text { Номер } \\
\text { предприятия }\end{array}$} & \multicolumn{9}{|c|}{ Показатели } \\
\cline { 2 - 10 } & $\mathbf{1}$ & $\mathbf{2}$ & $\mathbf{3}$ & $\mathbf{4}$ & $\mathbf{5}$ & $\mathbf{6}$ & $\mathbf{7}$ & $\mathbf{R}_{\mathbf{i}}$ & Место \\
\hline 1 & 0,333 & 0,810 & 0,835 & 0,510 & 0,335 & 1,000 & 0,209 & 2,008 & V \\
\hline 2 & 0,231 & 1,000 & 0,510 & 0,734 & 0,468 & 0,682 & 0,552 & 2,043 & IV \\
\hline 3 & 1,000 & 0,562 & 0,640 & 1,000 & 0,433 & 0,537 & 0,510 & 2,164 & II \\
\hline 4 & 0,591 & 0,722 & 0,394 & 0,889 & 1,000 & 0,822 & 0,734 & 2,270 & I \\
\hline 5 & 0,178 & 0,490 & 0,594 & 0,470 & 0,177 & 0,597 & 0,000 & 1,583 & VI \\
\hline 6 & 0,333 & 0,640 & 1,000 & 0,326 & 0,306 & 0,921 & 1,000 & 2,127 & III \\
\hline
\end{tabular}

Этап 4. Полученные рейтинговые оценки $\left(\mathrm{R}_{\mathrm{j}}\right)$ различаются по ранжиру, и определяется место каждого предприятия по результатам хозяйствования.

Преимущества многомерного сравнительного анализа:

1. Базируется на комплексном многомерном подходе к оценке производственно-финансовой деятельности предприятий.

2. Учитывает реальные достижения всех предприятий-конкурентов и степень их близости к показателям предприятия - эталона.

3. Предлагаемая методика делает количественно измеримой оценку надежности делового партнера, что позволяет избежать субъективизма и более реально оценивать рейтинг предприятий.

3. Способы приведения показателей в сопоставимый вид. Важное условие, которое нужно соблюдать при анализе - необходимость 
обеспечения сопоставимости показателей, поскольку сравнивать можно только качественно однородные величины. При этом должны быть учтены следующие требования:

- единство объемных, стоимостных, качественных, структурных факторов;

- единство промежутков или моментов времени, за которые были исчислены сравниваемые показатели;

- сопоставимость исходных условий производства (технических, природных и т.д.);

- единство методики исчисления показателей и их состава.

Сопоставимость показателей в ряде случаев может быть достигнута, если вместо абсолютных величин взять средние или относительные. Нельзя, например, сравнивать такие абсолютные показатели разных хозяйств, как объем производства продукции, стоимость основных средств, сумму прибыли и т.д. без учета земельной площади. Но если вместо абсолютных показателей взять относительные, например производство продукции на 100 га с/х площади, то их можно сравнить.

В некоторых случаях для обеспечения сопоставимости показателей используются поправочные коэффрициентыл.

Очень важно также при сравнении показателей обеспечить их сопоставимость по природно-климатическим условиям. Особенно это актуально для с/х.

Нельзя также допустить, чтобы сравниваемые показатели были неоднородны по составу затрат, количеству учитываемых объектов и др. Нельзя, например, сопоставлять показатели цеха с показателями завода в целом, себестоимость валовой и себестоимость реализованной продукции и т.д.

Таким образом, основными способами приведения показателей в сопоставимый вид являются нейтрализация стоимостного, объемного, 
качественного и структурного факторов путем приведения их к единому базису, а также использование средних и относительных величин, поправочных коэффициентов, методов пересчета и т.д.

\section{4. Способы использования относительных и средних величин в}

AХД. Экономический анализ изучает экономические явления, которые имеют, как правило, количественную определенность и выражаются в абсолютных и относительных величинах.

Абсолютные величины показывают количественные размеры явления в единицах меры, веса, объема, площади, стоимости и т.д. безотносительно к размеру других явлений.

Относительные показатели отражают соотношение величины изучаемого явления с величиной какого-либо другого явления или с величиной этого явления, но взятой за другое время или по другому объекту. Относительные величины получают в результате деления одной величины на другую, которая принимается за базу сравнения. Это могут быть данные плана, базисного года, другого предприятия и т.д. Относительные величины выражаются в форме коэффициентов или процентов.

В АХД используются следующие виды относительных величин:

1) относительная величина планового задания представляет собой отношение планового уровня показателя текущего года к его уровню в прошлом году или к среднему за 3-5 предыдущих лет;

2) относительная величина выполнения плана - это отношение между фактическим и плановым уровнем показателя, выраженное в процентах;

3) относительные величины динамики используют для характеристики изменения показателей за какой-либо промежуток времени. Их определяют путем деления величины показателя текущего года на его уровень в предыдущем периоде. Называются они темпами 
роста (прироста) и выражаются обычно в процентах или коэффициентах. Относительные величины динамики могут быть базисными и цепными. В первом случае каждый следующий уровень динамического ряда сравнивается с базисным годом, а в другом - каждый следующий год относится к предыдущему;

4) показатель структуры - это относительная доля (удельный вес) части в общем, выраженная в процентах или коэффициентах (например, удельный вес рабочих в общем количестве работников предприятия);

5) относительные величины координации представляют собой соотношение частей целого между собой (например, активной и пассивной части ОПФ);

6) относительные величины интенсивности характеризуют степень распространенности, развития какого-либо явления в соответствующей среде (степень заболеваемости населения);

7) относительные величины эффективности - это соотношение эффекта с ресурсами (затратами) (например, производство продукции на 100 га с/х площади).

На практике наряду с абсолютными и относительными величинами очень часто применяются средние величины. Они используются в АХД для обобщенной количественной характеристики совокупности однородных явлений по какому-либо признаку. Например, средняя з/п рабочих используется для обобщающей характеристики уровня оплаты труда изучаемой совокупности рабочих.

В АХД используются разные типы средних величин: среднеарифметические, среднегармонические, среднегеометрические и др.

При использовании средних величин в АХД следует учитывать, что они дают обобщенную характеристику явлений, основываясь на массовых данных. В этом их сила и недостаток. Нередко бывает, что за общими средними показателями, которые выглядят довольно неплохо, скрываются 
результаты плохо работающих бригад, цехов и других производственных подразделений. За средними данными не видно и достижения передовиков производства. Поэтому при анализе необходимо раскрывать содержание величин, дополняя их среднегрупповыми, а в некоторых случаях и индивидуальными показателями.

\section{5. Способы группировки информации в АХД.}

Широкое применение в АХД находит группировка информации деление массы изучаемой совокупности объектов на качественно однородные группы по соответствующим признакам. Группировка в анализе помогает разъяснить смысл средних величин, показать роль отдельных единиц в этих средних, выявить взаимосвязь между изучаемыми показателями.

В зависимости от задач используются следующие виды группировок:

a) типологические (группы предприятий по форме собственности и т.д.);

б) структурные позволяют изучать внутреннее строение показателей, соотношения в нем отдельных частей. С их помощью изучают состав рабочих по профессиям, стажу работы и т.д.;

в) аналитические (причинно-следственные) используются для определения наличия, направления и формы связи между изучаемыми показателями.

По сложности построения различают два типа группировок $\underline{\text { npocmble }}$ и комбинированные. С помощью простых группировок изучается взаимосвязь между явлениями, сгруппированными по какому-либо одному признаку. В комбинированных группировках такое деление изучаемой совокупности делается сначала по одному признаку, а потом внутри каждой группы - по другому признаку и т.д. Такие группировки позволяют изучать очень разнообразные и сложные взаимосвязи. Но их недостаток заключается в том, что их построение отличается высокой 
трудностью, а полученные результаты очень трудно воспринимаются. Поэтому для изучения сложных взаимосвязей лучше такую группировку заменить несколькими простыми.

Таким образом, правильная группировка информации дает возможность изучать зависимость между показателями, более глубоко разобраться в сущности изучаемых явлений, систематизировать материалы анализа, определить главное, характерное и типичное.

6. Балансовый способ в АХД. Балансовый способ служит для отражения соотношений, пропорций двух групп взаимосвязанных и уравновешенных экономических показателей, итоги которых должны быть тождественными.

Этот способ широко используется при анализе обеспеченности предприятия трудовыми, финансовыми ресурсами, сырьем, материалами и т.д., а также при анализе полноты их использования.

Определяя, например, обеспеченность предприятия трудовыми ресурсами, составляют баланс, в котором, с одной стороны, показывается потребность в трудовых ресурсах, а с другой стороны - фактическое их наличие.

Для определения платежеспособности предприятия используется платежный баланс, в котором соотносятся платежные средства с платежными обязательствами.

Как вспомогательное средство балансовый метод используется в АХД для проверки исходных сведений, на основе которых проводится анализ, а также для проверки правильности собственно аналитических расчетов. В некоторых случаях балансовый способ может быть использован для определения величины влияния отдельных факторов на прирост результативного показателя.

7. Использование графического способа в АХД. Графики представляют собой масштабное изображение показателей, чисел с 
помощью геометрических знаков или условно-художественных фигур. Благодаря им изучаемый материал становится более доходчивым и понятным.

Большое и аналитическое значение графиков. В отличие от табличного материала график дает обобщающий рисунок положения или развития изучаемого явления, позволяет зрительно заметить те закономерности, которые содержит числовая информация. На графике более выразительно проявляются тенденции и связи изучаемых показателей.

Основные формы графиков, которые используются в АХД - это диаграммы.

По форме диаграммы бывают: а) столбиковые; б) полосовые; в) круговые; г) квадратные; д) линейные: е) фигурные.

По содержанию различают диаграммы:

а) сравнения - показывают соотношения разных объектов по какомулибо показателю. Наиболее наглядным графиком для сравнения величин показателей является столбиковые и полосовые диаграммы. Для их составления используют прямоугольную систему координат;

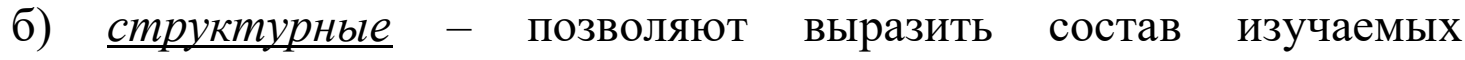
показателей, удельный вес отдельных частей в общей величине показателя. Изображение показателя дается в виде разбитых на сектора геометрических фигур (квадратов, кругов), площадь которых берется за 100 или 1;

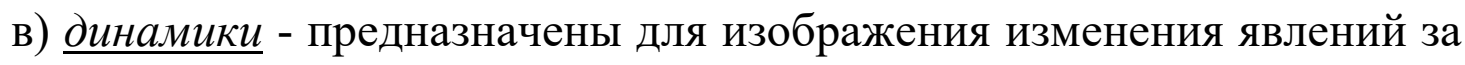
соответствующие промежутки времени;

г) контроля - находят широкое применение в АХД при изучении сведений о ходе выполнения план. В таком случае на графике будут две линии: плановый и фактический уровень показателей за каждый день или другой промежуток времени. 
Графические способы могут использоваться и при решении методических задач АХД и в первую очередь при построении разнообразных схем для наглядного изображения внутреннего строения изучаемого объекта, последовательности технологических операций, взаимосвязей между результативными и факторными показателями и т.д.

\section{8. Способы табличного отражения аналитических данных.} Результаты анализа обычно излагаются в виде таблиц. Это наиболее рациональная и удобная для восприятия форма предоставления аналитической информации об изучаемых явлениях при помощи цифр, расположенных в определенном порядке.

Существуют три вида таблиц:

a) npocmble, в которых перечисляются единицы совокупности характеризуемого явления;

б) гpynnoвые, в которых данные по отдельным единицам изучаемой совокупности объединяются в группы по одному существенному признаку;

г) комбинированные, в которых материал подлежащего разбивается на группы и подгруппы по нескольким признакам.

\section{Tема 5}

\section{Методика факторного анализа}

1. Понятие, типы и задачи факторного анализа.

2. Классификация факторов в экономическом анализе.

3. Систематизация факторов в экономическом анализе.

4. Понятие детерминированного моделирования и основные типы факторных моделей.

1. Понятие, типы и задачи факторного анализа. Под факторнылм анализом понимается методика комплексного и системного изучения и 
измерения воздействия факторов на величину результативных показателей.

Типы факторного анализа:

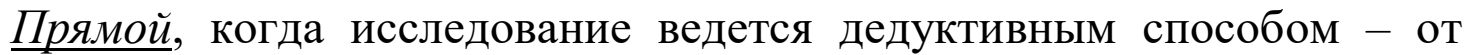
общего к частному.

Детерминированный представляет собой методику, когда результативный показатель представлен в виде произведения, частного или алгебраической суммы факторов.

Статический применяется при изучении влияния факторов на результативные показатели на соответствующую дату.

Обратный, когда исследование осуществляется способом логичной индукции - от частных, отдельных факторов к обобщающим.

Многоступенчатыц̆, когда проводится детализация факторов на составляющие элементы с целью изучения их поведения.

Одноступенчатый используется для исследования факторов только одного уровня подчинения, без их детализации на составные части.

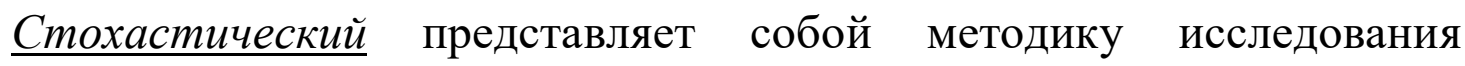
факторов, связь которых с результативным показателем является неполной, вероятностной. Например, производительность труда при одном и том же уровне фондовооруженности может быть неодинаковой на разных предприятиях. Это зависит от оптимальности сочетания других факторов, воздействующих на этот показатель.

Перспективныцй исследует поведение факторов и результативных показателей в перспективе.

Динамический представляет собой методику исследования причинноследственных связей в динамике.

Pетроспективныцй изучает причины прироста результативных показателей за прошлые года.

Основные задачи факторного анализа: 
1. Отбор факторов, определяющих исследуемые результативные показатели.

2. Классификация и систематизация факторов с целью обеспечения комплексного и системного подхода к исследованию их влияния на результаты хозяйственной деятельности.

3. Определение формы зависимости между факторами и результативным показателем.

4. Моделирование взаимосвязей между результативными и факторными показателями.

5. Расчет влияния факторов и оценка роли каждого из них в изменении величины результативного показателя.

6. Работа с факторной моделью.

2. Классификация факторов в экономическом анализе. По своей природе факторы подразделяются на:

Природно-климатические - оказывают влияние на результаты хозяйственной деятельности в с/x, лесном хозяйстве и т.д.

Сочиально-экономические способствуют более полному использованию производственных ресурсов предприятия и повышению эффективности его работы (жилищные условия его работников, организация оздоровительной работы на предприятии, уровень образования кадров и т.д.).

Производственно - экономические определяют полноту и эффективность использования производственных ресурсов предприятия и конечные результаты его деятельности.

По степени воздействия на результаты хозяйственной деятельности факторы делятся на:

Ocновные, которые оказывают решающее воздействие на результативный показатель.

Bmopocmenенные, которые не оказывают решающего воздействия на 
результаты хозяйственной деятельности в сложившихся условиях.

По местам возникновения факторы делятся на:

Bнутренние, которые зависят от деятельности предприятия.

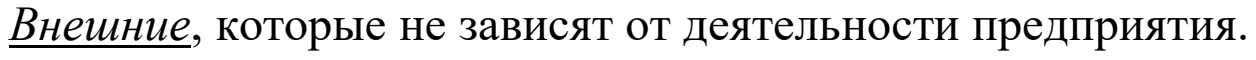

По зависимости от человека факторы делятся на:

Oбъективные, которые не зависят от воли и желаний людей (стихийное бедствие).

Субъективные, которые зависят от деятельности физических и юридических лиц.

По степени распространенности факторы делятся на:

Общие, которые действуют во всех отраслях экономики.

Специфические, которые действуют в условиях отдельной отрасли экономики или предприятия.

По сроку воздействия на результаты хозяйственной деятельности факторы делятся на:

Постоянные, которые оказывают влияние на изучаемое явление беспрерывно на протяжении всего времени.

Переменные, воздействие которых проявляется периодически (освоение новой техники).

По характеру деятельности факторы делятся на:

Интенсивные характеризуют степень усилия, напряженности труда в процессе производства.

Экстенсивные связаны с количественным приростом результативного показателя (повышение количества рабочих).

По свойствам отражаемых явлений факторы делятся на:

Количественные - выражают количественную определенность явлений (количество сырья).

Качественные - определяют внутренние качества, особенности изучаемых объектов (качество продукции). 
По своему составу факторы делятся на:

Сложные состоят из нескольких элементов (производительность труда).

Простые не раскладываются на составные части (количество рабочих дней в отчетном периоде).

По иерархии факторы делятся на:

Факторы первого уровня непосредственно влияют на результативный показатель (среднегодовая численность рабочих).

Факторы второго уровня определяют результативный показатель косвенно, при помощи факторов первого уровня (количество отработанных дней одним рабочим).

3. Систематизация факторов в экономическом анализе. Системный подход в АХД вызывает необходимость взаимосвязанного изучения факторов с учетом их внутренних и внешних связей, взаимодействия и взаимоподчинености, что достигается с помощью их систематизации. Систематизация в целом - это размещение изучаемых явлений или объектов в определенном порядке с выявлением их взаимосвязи и подчиненности.

Одним из способов систематизации факторов является создание детерминированных факторных систем. Создать факторную систему значит представить изучаемое явление в виде алгебраической суммы, частного или произведения нескольких факторов, что воздействуют на его величину и находятся с ним в функциональной зависимости.

Например, объем валовой продукции промышленного предприятия можно представить в виде произведения двух факторов первого порядка: среднего количества рабочих и среднегодовой выработки продукции одним рабочим за год, которая в свою очередь зависит непосредственно от количества отработанных дней одним рабочим за год и среднедневной 
выработки продукции одним рабочим. Последняя также может быть разложена на продолжительность рабочего дня и среднечасовую выработку.

Развитие детерминированной факторной системы достигается, как пр. (пример), за счет детализации комплексных факторов. Элементные факторы (количество рабочих, продолжительность рабочего дня) не раскладываются на сомножители, так как по своему содержанию они однородны. С развитием системы количественные факторы постепенно детализируются на менее общие, те в свою очередь еще на менее общие. Однако, необходимо заметить, что развитие факторных систем до необходимой глубины связано с некоторыми методологическими трудностями и прежде всего с трудность нахождения факторов общего характера, которые можно было бы представить в виде произведения, частного или алгебраической суммы нескольких факторов. Поэтому обычно детерминированные системы охватывают наиболее общие факторы. Между тем исследование более конкретных факторов в экономическом анализе имеет большее значение, чем общих.

Большое значение в исследовании взаимосвязей имеет качественныцй (логический) анализ структуры взаимосвязи между изучаемыми показателями. Он позволяет установить наличие или отсутствие причинноследственных связей между исследуемыми показателями, изучить направление связи, форму зависимости, что очень важно при определении степени их влияния на изучаемое явление и при обобщении результатов анализа.

Анализ структуры связи изучаемых показателей осуществляется с помощью построения блок-схемы, которая позволяет установить наличие и направление связи не только между изучаемыми факторами и результативным показателем, но и между самими факторами. Построив блок-схему, можно увидеть, что среди изучаемых факторов имеются такие, 
которые более или менее непосредственно воздействуют на результативный показатель, и такие, которые воздействуют не столько на результативный показатель, сколько друг на друга.

Например, рассмотрим взаимосвязь между себестоимостью единицы продукции растениеводства и такими факторами, как урожайность культур, производительность труда, количество внесенных удобрений, качество семян, степень механизации производства.

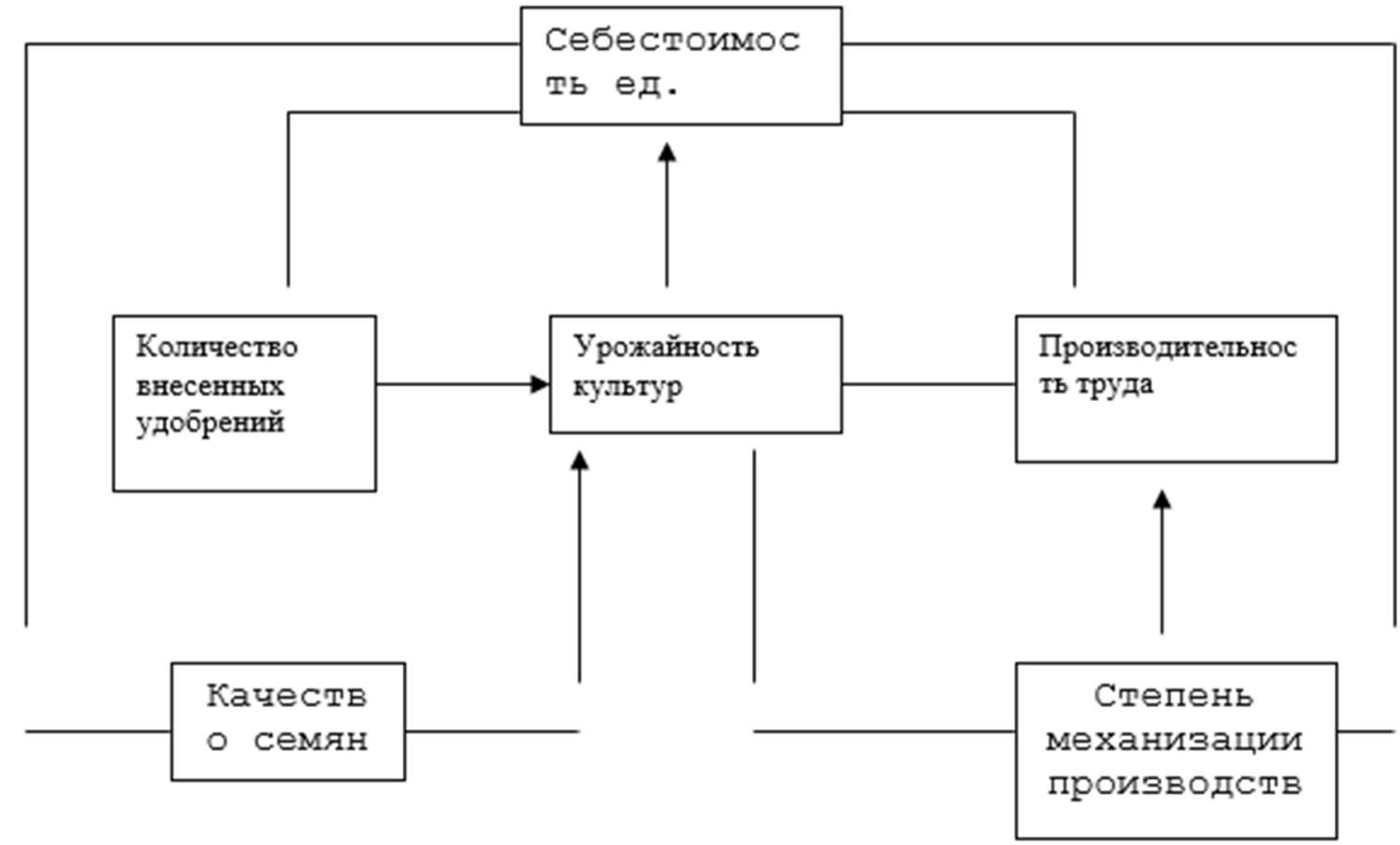

Прежде всего, необходимо установить наличие и направление связей между себестоимостью продукции и каждым фактором. Непосредственное влияние на себестоимость оказывает в данном примере только урожайность культур. Все остальные факторы влияют на себестоимость не только прямо, и косвенно через урожайность культур и производительность труда, например, количество внесенных удобрений в почву содействует повышению урожайности культур, что обуславливает снижение себестоимости единицы продукции. Однако, необходимо 
учитывать и то, что повышение количества внесенных удобрений приводит к росту суммы затрат на гектар посева. И если сумма затрат возрастает более высокими темпами, чем урожайность, то себестоимость продукции будет возрастать. Аналогично влияет на себестоимость продукции и качество семян. Приобретение элитных, высококачественных семян вызовет рост суммы затрат. Если они увеличатся в большей степени, чем урожайность от применения высококачественных семян, то себестоимость продукции будет возрастать.

Повышение уровня механизации вызовет рост затрат на содержание основных средств производства. Однако, при этом увеличится производительность труда, растет урожайность, что содействует снижению себестоимости продукции.

Исследование взаимосвязей между факторами показывает, что из всех изучаемых факторов отсутствует причинно-следственная связь между качеством семян, количеством удобрений и механизацией производства. Отсутствует также непосредственная обратная зависимость данных показателей от уровня урожайности культуры. Все остальные факторы прямо или косвенно влияют друг на друга.

Таким образом, систематизация факторов позволяет более глубоко изучить взаимосвязь факторов при формировании величины изучаемого показателя, что имеет очень важное значение на следующих этапах анализа, особенно на этапе моделирования исследуемых показателей.

4. Понятие детерминированного моделирования и основные типы факторных моделей. Одной из задач факторного анализа является моделирование взаимосвязей между результативными показателями и факторами, которые определяют их величину.

Моделирование - это один из важнейших методов научного познания, с помощью которого создается модель (условный образ) объекта исследования. Сущность его заключается в том, что взаимосвязь 
исследуемого показателя с факторными передается в форме конкретного математического уравнения.

В факторном анализе различают модели детерминированные (функциональные) и стохастические (корреляционные).

При моделировании детерминированных факторных систем необходимо выполнять ряд требований:

1. Факторы, которые включены в модель, и сами модели должны иметь определенно выраженный характер, реально существовать, а не быть придуманными абстрактными величинами или явлениями.

2. Факторы, которые входят в систему, должны быть не только необходимыми элементами формулы, но и находится в причинноследственной связи с изучаемыми показателями.

3. Все показатели факторной модели должны быть количественно измеримы, т.е. должны иметь единицу измерения и необходимую информационную обеспеченность.

4. Факторная модель должна обеспечивать возможность измерения влияния отдельных факторов, это значит, что в ней должна учитываться соразмерность изменений результативного и факторных показателей, а сумма влияния отдельных факторов должна быть равна общему приросту результативного показателя.

В детерминированном анализе выделяют следующие типы наиболее часто встречающихся факторных моделей:

1. Аддитивные модели используются в тех случаях, когда результативный показатель представляет собой алгебраическую сумму нескольких факторных показателей.

2. Мультипликативные модели применяются, когда результативный показатель представляет собой произведение нескольких факторов.

3. Kратные модели применяются, когда результативный показатель получают делением одного факторного показателя на величину другого. 
4. Смешанные (комбинированные) модели - это сочетание в различных комбинациях предыдущих моделей.

Моделирование мультипликативных факторных систем в АХД осуществляется путем последовательного расчленения факторов исходной системы на факторы - сомножители. Эти модели отражают процесс детализации исходной факторной системы и расширения еe за счет расчленения на сомножители комплексных факторов. Степень детализации и расширения модели зависит от цели исследования, а также от возможностей детализации и формализации показателей в пределах установленных правил.

Аналогичным образом осуществляется моделирование аддитивных факторных систем за счет расчленения одного из факторных показателей на его составные элементы.

К классу кратных моделей применяются следующие способы их преобразования:

1. Способ удлинения предусматривает удлинение числителя исходной модели путем замены одного или нескольких факторов на сумму однородных показателей. Например:

$$
\text { Себестоимость }=\frac{3 \text { атрать }}{\text { объемВП }}
$$

Общую сумму затрат можно заменить отдельными элементами: оплата труда (ОТ), сырьё и материалы(СМ), амортизация основных средств (А), накладные затраты (Н3).

$$
C=\frac{O T}{\text { объемВП }}+\frac{C M}{\text { объемВП }}+\frac{A}{\text { объемВП }}+\frac{H 3}{\text { объемВП }}=x_{1}+x_{2}+x_{3}+x_{4}
$$

2. Способ формального разложения факторной системы предусматривает удлинение знаменателя исходной факторной модели путем замены одного или нескольких факторов на $\sum(\mathrm{x})$ однородных показателей. 
3. Метод расширения предусматривает расширение исходной факторной модели за счет умножения числителя и знаменателя дроби на один или несколько новых показателей. Например, исходная модель $\mathrm{y}=\mathrm{a} / \mathrm{b}$, введем новый показатель «с», то модель примет вид

$$
y=\frac{a \cdot c}{b \cdot c}=\frac{a}{c} \cdot \frac{c}{b}=x_{1} \cdot x_{2}
$$

4. Способ сокращения представляет собой создание новой факторной модели путем деления числителя и знаменателя дроби на один и тот же показатель.

Таким образом, результативные показатели могут быть разложены на составные элементы (факторы) различными способами и представлены в виде различных типов детерминированных моделей. Выбор способа моделирования зависит от объекта исследования, поставленной цели, а также от профессиональных навыков и знаний исследователя.

Процесс моделирования факторных систем - очень сложный и ответственный момент в АХД. От того, насколько реально и точно созданные модели отражают связь между исследуемыми показателями, зависят конечные результаты анализа.

\section{Tема 6}

\section{Методика функционально-стоимостного анализа.}

1. Понятие ФСА и его задачи.

2. Принципы организации ФСА.

3. Этапы проведения ФСА.

1. Понятие ФСА и его задачи. ФСА представляет собой эффективный способ выявления резервов сокращения затрат, который основывается на поиске более дешевых способов выявления главных 
функций (путем организационных, технических, технологических и др. изменений производства) при одновременном исключении лишних функций.

Конечной целью ФСА является поиск наиболее экономичных, с точки зрения потребителя и производителя, вариантов того или иного практического решения. Для достижения этой цели с помощью анализа должны решаться следующие задачи:

- обобщающая характеристика объекта исследования;

- детализация объекта на функции;

- группировка выделенных функций на главные, дополнительные и ненужные;

- определение и группировка затрат соответственно выделенным функциям;

- исчисление суммы затрат на изготовление изделия при исключении лишних функций и использовании других технических и технологических решений;

- разработка предложений по технологическому и организационному усовершенствованию производства.

Объектом ФСА могут быть как отдельные виды изделий, так и ехнологические процессы.

2. Принципы организации ФСА. С целью обеспечения наибольшей отдачи от выполнения работ по ФСА необходимо соблюдать ряд основных правил при проведении аналитического исследования. Наиболее важными являются следующие:

Принщип ранней диагностики. Сущность его состоит в том, что величина выявленных резервов зависит от того, на какой стадии жизненного цикла изделия проводится ФСА: предпроизводственной, производственной, эксплуатации, утилизации. Как пр., излишние затраты в основном закладываются на этапе проектирования. Следовательно, 
наибольший эффект от проведения анализа может быть получен на этом этапе. Когда можно предупредить излишние затраты не только на изготовление изделия, но и на подготовку его производства. На стадии промышленного выпуска продукции размер эффекта снизится за счет того, что уже проведены работы по обеспечению его функционирования и налажен производственный процесс. Вмешательство в этот процесс не обойдется без потерь. Еще большие потери будут при внесении изменений в конструкцию изделия на стадии его эксплуатации. Поэтому наиболее целесообразно проводить ФСА при конструкторской разработке изделий.

Приниип приоритета. Так как метод ФСА не имеет пока широкого распространения и не охватывает все возможные объекты, а количество специалистов, которые владеют методикой, ограничено, в каждом случае необходимо учитывать следующее требование. В первую очередь ФС анализу должны подлежать изделия и процессы, которые находятся на стадии конструкторской разработки и будут производится в больших масштабах. Это позволит, с одной стороны, максимизировать эффект ФСА при минимально возможных затратах на его проведение. Кроме того, значительный эффект, полученный в этом случае будет способствовать более широкому признанию ФСА.

Приниип оптимальной детализации. Главный смысл ФСА выделение потребительских функций, свойственных объекту. Но если исследуемый объект достаточно сложный, то в результате его деления на функции, последних может образоваться очень много. Такая узкая детализация делает очень громоздкой, малопонятной программу анализа и вряд ли будет способствовать быстроте и результативности его выполнения. Если на практике встречается проблема исследования сложных объектов, то ее лучше решать в два этапа:

1) деление объекта на крупные части (отдельные узлы машин или приспособления, обособленные группы технологических операций); 
2)выполнение ФСА каждого из выделенных более мелких объектов.

В отдельных случаях при предварительной детализации может выясниться, что наиболее интересной для анализа является какая-либо одна часть объекта. Выделение же остальных целесообразно с точки зрения эффективности анализа.

Принци последовательности. Выполнение комплекса работ по ФСА требует определенной последовательности в исследовании, прежде всего предварительного изучения будущего объекта и всех обстоятельств, которые связаны с его производством и использованием. При этом необходимо пользоваться логической схемой детализации от общего к частному (объект - узел - функция). Следует иметь в виду, что при выполнении ФСА результаты его проведения на каждом этапе зависят от полноты и качества выполненных работ на предыдущих этапах.

Приниип выделения ведущего звена (ликвидации узких мест). Почти всегда при анализе выясняется, что или в хозяйственном комплексе, или в отдельно взятом изделии существует какая то часть, которая требует больших затрат на обеспечение жизнеспособности этого объекта или сдерживает получение эффекта от его использования. Очевидно, что с точки зрения анализа исследование наиболее целесообразно направить на ликвидацию этих сдерживающих обстоятельств. Благодаря такому выбору направления исследования, минимальные затраты на проведение ФСА приведут к активизации всей анализируемой системы и значительно повысят общий эффект от ее функционирования.

Использование изложенных принципов может существенно повысить эффективность работы по ФСА.

3. Этапы проведения ФСА. При описании последовательности проведения ФСА выделяют семь этапов.

Подготовительный этап. Одной из задач, которая должна решаться на этом этапе, является популяризация метода, в результате чего создаются 
благоприятные условия для выполнения определенных аналитических исследований. Тут же выбирается объект будущего исследования, создается временная исследовательская группа из специалистов разного направления для более полного охвата всех инженерно-экономических и технологических особенностей объекта. На этом этапе разрабатывается подробный календарный план выполнения исследования, кроме того, оформляются все нормативные документы, которые связаны с проведением ФСА.

Информационный этап. Главная задача, которая решается на этом этапе - сбор, изучение и обобщение разнообразных данных об исследуемом объекте. Они должны отражать условия производства, реализации и потребления изделия, новейшие достижения в отраслях науки и техники так или иначе связанных с этим объектом, удерживать всю без исключения экономическую информацию, имеющую отношение к анализируемому объекту. Данный этап нередко называют фундаментом ФСА, потому что от полноты и достоверности собираемой информации во многом зависит успех последующих этапов ФСА.

Аналитический этап. На данном этапе прежде всего проводится детализация изучаемого объекта на функции, их классификация, определение стоимости каждой из них. Практически это означает создание ФС модели объекта. В результате проведенных исследований должны быть выявлены зоны наибольшей концентрации затрат, т.е. наиболее перспективные зоны с точки зрения задач ФСА. На основании этого формулируются задачи по усовершенствованию объекта с целью сокращения затрат на его производство, выбираются направления дальнейшего исследования.

Творческий этап. На этом этапе осуществляется разработка вариантов упрощения и удешевления конструкции изделия или технологии. Здесь решаются задачи по совмещению функций, 
возможности ликвидации ненужных функций, удешевления элементов конструкции, устанавливаются разные варианты выполнения основных функций, производится обсуждение наиболее реальных вариантов с точки зрения реализации.

В разработке предложений участвует весь творческий коллектив. В качестве экспертов могут привлекаться и другие специалисты. На заключительном этапе из общего количества предложений должно остаться 2-3 наиболее привлекательных и перспективных, по мнению специалистов, вариантов усовершенствования объекта. К тому же эти предложения требуют более детального исследования, а иной раз и экспериментальной проверки.

\section{Исследовательский этап. Экспериментальная проверка} выдвинутых предположений - главная задача исследовательского этапа. Для ее решения обычно проводятся все необходимые технические, технологические и экономические расчеты, проверяется соответствие нового варианта продукции условиям его использования потребителями. Если расчетов недостаточно, то создаются исследуемые образцы объекта и проводится их испытание как с точки зрения приспособленности к существующему производственному оборудованию, так и с точки зрения условий доставки до потребителя и эксплуатации.

Рекомендательный этап. На этом этапе должен быть сделан окончательный выбор варианта изменения исследуемого объекта, который бы не снизил его потребительских качеств. При этом оформляется вся необходимая документация по выбранному варианту усовершенствования объекта, происходит согласование многих вопросов с органами Госстандарта, пожарными, санитарными, экологическими и др. службами. Здесь разрабатываются планы - графики внедрения результатов анализа в производство.

Этап внедрения. Это последний этап по всему циклу ФСА. После 
его окончания должны быть решены все вопросы, связанные с организацией производства нового варианта анализируемого изделия. На протяжении всего срока освоения нового варианта должен осуществляться контроль со стороны специалистов временного творческого коллектива. На этом же этапе подводятся результаты проведенной работы, определяется экономический эффект от ее проведения, оформляется отчет о результатах анализа, решаются вопросы материальной заинтересованности участников разработки и внедрения результатов ФСА.

\section{$\underline{\text { Tема } 7}$}

Методика выявления и подсчета резервов в экономическом анализе

1. Понятие, экономическая сущность хозяйственных резервов и их классификация.

2. Принципы организации поиска и подсчета резервов.

3. Методика подсчета и обоснования величины резервов.

1. Понятие, экономическая сущность хозяйственных резервов и их классификация. Слово «резерв» происходит или от французского "reserve" - «запас» или от латинского "reservere" - «сберегать», «сохранять». В связи с этим в специальной литературе термин «резервы» употребляется в двояком значении. Во-первых, резервами считаются запасы ресурсов (сырья, материалов, топлива и т.д.), которые необходимы для бесперебойной работы предприятия. Во-вторых, резервами считаются возможности повышения эффективности производства.

Чтобы избежать путаницы между этими понятиями мы будем употреблять термин «резервные фонды» как запасы материальных ресурсов и термин «хозяйственные резервы» как возможности развития производства относительно достигнутого уровня на основе использования 
достижений НТП.

Экономическая сущность резервов и их объективный характер могут быть правильно раскрыты на основе всеобего закона экономии времени, т.е. в более рациональном использовании материальных и трудовых ресурсов.

Постоянная экономия рабочего времени представляет собой природу возникновения резервов. С развитием НТП появляются все новые и новые возможности роста производительности труда, экономного использования сырья и других ресурсов, т.е. источники резервов неисчерпаемы.

Таким образом, экономическая сущность резервов повышения эффективности производства состоит в более полном и рациональном использовании все возрастающего потенциала ради получения большего количества высококачественной продукции при наименьших затратах живого и овеществленного труда на единицу продукции.

Классификация хозяйственных резервов:

По пространственному признаку:

Bнутрихозяйственные, которые выявляются и могут быть использованы только на исследуемом предприятии. Они связаны с ликвидацией потерь и непроизводственных затрат ресурсов.

Ompacлевые, которые могут быть выявлены только на уровне отрасли (выведение новых сортов культур).

Региональные могут быть выявлены и использованы в пределах географического района (использование сырья и топлива).

Общегосударственные, к которым можно отнести ликвидацию диспропорции в развитии разных отраслей производства, изменение форм собственности и т.д.

По признаку времени:

Неиспользованные резервы - это упущенные возможности повышения эффективности производства относительно плана или 
достижений науки и передового опыта за прошедшие промежутки времени.

$\underline{\text { Текушие резервы }}$ - это возможности улучшения резервов хозяйственной деятельности, которые могут быть реализованы на протяжении ближайшего времени.

Перспективные резервьи рассчитаны на долгое время. Их использование связано со значительными инвестициями, внедрением достижений НТП, смены технологии производства и т.д.

Большое значение для организации поиска резервов имеет их группировка по стадиям жизненного цикла изделия.

На предпроизводственной стадии изучается потребность в изделии, свойства, которыми оно обладает, разрабатываются конструкции изделия, технология его производства. Здесь могут быть выявлены резервы повышения эффективности производства за счет улучшения конструкции изделия, применения более дешевого сырья и т.д. На этой стадии содержатся самые большие резервы снижения себестоимости продукции.

На производственной стадии происходит освоение новых изделий, новой технологии и затем осуществляется массовое производство продукции. На этом этапе величина резервов снижается за счет того, что уже проведены работы по созданию производственных мощностей, приобретению необходимого оборудования и инструментов. На этой стадии выявляются и используются в качестве резервов те излишние затраты ресурсов, которые не затрагивают производственного процесса (улучшение организации труда, повышение его интенсивности, экономия сырья и материалов).

Эксплуатационная стадия. На стадии эксплуатации объекта резервы более производительного его использования и снижения затрат зависят от качества выполненных работ на первых двух стадиях. 
По стадиям процесса воспроизводства резервы бывают в $\underline{\text { сфере }}$ производства и в сфере обращения. Основные резервы находятся в сфере производства, но они есть и в сфере обращения (предотвращение потерь продукции на пути от производителя к потребителю, снижение затрат, связанных с хранением, перевозкой, продажей готовой продукции).

Важное значение в экономическом анализе имеет группировка резервов по основным трем моментам процесса труда (эффективное использование основных средств производства, предметов труда и трудовых ресурсов). Если по какому-либо ресурсу резервов не хватает, то в расчет принимается наименьшая величина резервов, выявленная по одному из них.

По характеру воздействия резервы делятся на:

Экстенсивные связанны с использованием в производстве дополнительных ресурсов (материальных, трудовых, земельных и др.)

Интенсивные связаны с наиболее полным и рациональным использованием имеющегося производственного потенциала. $\mathrm{C}$ ускорением НТП ослабевает роль резервов экстенсивного характера, и усиливается поиск резервов интенсификации производства.

Группировка резервов по уровню затратоёмкости их освоения:

Первая группа резервов требует наименьших затрат за счет сокращения потерь сырья и готовой продукции.

Bторая группа резервов требует значительных затрат за счет внедрения достижений науки и передовой практики без коренной реконструкции производства.

Третья группа резервов связана с реконструкцией и техническим переоснащением производства в связи с использованием новейших достижений НТП.

По способам выявления резервы делятся на:

Явные, которые легко выявляются по материалам бухучета и 
отчетности. Они могут быть:

a) безусловные, связанные с недопущением безусловных потерь сырья и рабочего времени и отраженные в отчетности (недостача и порча продукции, производственный брак, потери от списания долгов и т.д.);

бц условные, к которым относятся перерасходы всех видов ресурсов по сравнению с предыдущими нормами на предприятии. Причины: неудовлетворительное состояние оборудования, низкий уровень организации производства, недостаточная квалификация рабочих и т.д.

Cкрытыле, которые связаны с внедрением достижений НТП и передового опыта, и которые не были предусмотрены планом. Для их выявления необходимо сделать внутрифирменный анализ (сравнения с достижениями передовых участков, бригад, работников), межхозяйственный (сравнения с достижениями ведущих предприятий отрасли).

По времени возникновения резервы могут быть:

Pезервы, не учтенные при разработке планов - это упущенные возможности повышения эффективности производства, существовавшие в момент разработки планов, но не учтенные, что является признаком недостаточной обоснованности и напряженности планов.

Резервьл, возникшие после утверждения планов - это возможности, возникшие после разработки и утверждения планов, это связано с быстрыми темпами НТП, появлением новых решений, новых возможностей.

Таким образом, классификация резервов позволяет более глубоко понять сущность и организовать их поиск.

\section{2. Принципы организации поиска и подсчета резервов.}

Принципы поиска резервов:

1. Научный характер основывается на положениях диалектической теории познания, знаниях экономических законов, достижениях науки и 
передовой практики.

2. Комплексный и системный подход означает, во-первых, выявление резервов по всем направлениям хозяйственной деятельности с последующим их обобщением, во-вторых, умение выявлять и обобщать резервы с учетом взаимосвязи и соподчиненности изучаемых явлений.

3. Предотвращение повторного счета резервов, который возникает при их обобщении, когда не учитывается воздействие различных факторов, от которых зависят результаты хозяйственной деятельности

4. Комплектность, т.е. сбалансированность по трем основным моментам процесса труда (средств труда, предметов труда и трудовых ресурсов). Наибольший резерв, выявленный по одному из ресурсов, не может быть реализован, если недостает резервов по другим ресурсам. Поэтому возникает необходимость проверки комплектности ресурсов.

5. Экономическая обоснованность, т.е. при их подсчете необходимо учитывать реальные возможности предприятия, а расчетная величина этих резервов должна быть подкреплена соответствующими мероприятиями.

6. Оперативность означает сокращение времени между выявлением и освоением резервов.

7. Поиск не должен быть дискретным. Его необходимо делать планомерно, систематически, ежедневно.

8. Массовость, т.е. привлечение к этому процессу всех работников с также развитие и усовершенствование общественных форм экономического анализа.

9. Необходимость выделять «ведущие звенья» или «узкие места» в повышении эффективности производства. Поэтому принципу выделяют участки производства, где систематически не выполняются планы, или имеются большие потери сырья, простои техники и т.д. Так определяются основные направления, по которым поиск резервов идет в первую очередь. 
3. Методика подсчета и обоснования величины резервов. Для того, чтобы величина выявленных резервов была реальной, подсчет резервов должен быть по возможности точным и обоснованным. Методика подсчета резервов зависит от характера резервов (интенсивные или экстенсивные), способов их выявления (явные или скрытые) и способов определения их величины (формальный подход или неформальный). При формальном подходе величина резервов определяется без увязки с конкретными мероприятиями по их освоению. Неформальный подход (выявление резервов по сущности) основывается на конкретных организационно-технических мероприятиях.

Для подсчета величины резервов в АХД используется ряд способов:

1. Способ прямого счета применяется для подсчета резервов в тех случаях, когда известна величина дополнительного привлечения или величина безусловных потерь ресурсов.

2. Способ сравнения применяется для подсчета величины резервов в тех случаях, когда потери ресурсов или возможная их экономия определяется в сравнении с плановыми нормами или с их затратами на единицу продукции на передовых предприятиях.

3. Способы детерминированного факторного анализа: цепной подстановки, абсолютных разниц, относительных разниц и интегральный метод.

4. Способь математического программирования, которые позволяют оптимизировать величину показателей с учетом условий хозяйствования и ограничений на ресурсы и тем самым выявить дополнительные и неиспользованные резервы производства путем сравнения величины исследуемых показателей по оптимизированному варианту с фактическим или плановым их уровнем.

5. Функиионально-стоимостной анализ (ФСА), главное назначение которого состоит в целенаправленной оптимизации соотношений между 
необходимыми, чрезмерными затратами и потребительскими свойствами изделия. Использование этого метода позволяет на ранних стадиях жизненного цикла изделия найти и предупредить лишние затраты путем усовершенствования его конструкции, технологии производства, исполнения более дешевого сырья и материалов.

6. Расчетно-конструктивный метод. Этот способ применяется в тех случаях, когда исследуемый результативный показатель можно представить в виде краткой модели.

Все выявленные таким способом резервы должны быть подкреплены соответствующими мероприятиями. Только в этом случае величина резервов будет реальной и обоснованной.

Это может осуществиться двумя способами:

a) формальными методами выявляются резервы, затем разрабатывается мероприятия, которые позволяют освоить выявленные резервы;

б) разрабатываются мероприятия, потом подсчитываются резервы.

Например, подсчитаны резервы повышения производства продукции за счет повышения уровня производительности труда работников до планового уровня. После этого разрабатывается мероприятие по освоению этого резерва (улучшение организации труда, совершенствование техники и технологии производства, повышение квалификации работников и т.д.). При этом сумма резервов по всем мероприятиям должна быть равна общей величине выявленных резервов роста производительности труда.

Наиболее обоснованным является второй способ подсчета резервов, в основу которого положены конкретные мероприятия с учетом реальных возможностей предприятия.

Такой неформальный подход к выявлению резервов позволяет более точно определить их величину. Но для этого нужна предварительная оценка эффективности (окупаемости) каждого мероприятия. 


\section{$\underline{\text { Teма } 8}$}

\section{Организация и информационное обеспечение экономического}

анализа

1. Основные правила организации анализа.

2. Организационные формы и исполнители экономического анализа деятельности предприятия.

3. Планирование аналитической работы.

4. Информационное обеспечение анализа.

5. Подготовка и аналитическая обработка исходных данных в анализе.

6. Документальное оформление результатов анализа.

7. Организация компьютерной обработки экономической информации.

1. Основные правила организации анализа. Организация экономического анализа на предприятии должна соответствовать ряду требований:

1.Научный характер анализа, т.е. анализ должен основываться на новейших достижениях науки и передового опыта, строиться с учетом действия экономических законов в рамках конкретного предприятия.

2. Обоснованное распределение обязанностей по проведению экономического анализа между отдельными исполнителями. От этого зависит не только полнота охвата объектов анализа, но и исключается возможность многократного проведения одних и тех же исследований разными лицами.

3. Эффективность , т.е. затраты на проведение исследований должны быть наименьшими при оптимальной глубине анализа и его 
комплексности.

Важным принципом организации аналитической работы на предприятии является ее регламентация и унификация. Регламентация предусматривает разработку для каждого исполнителя обязательного минимума таблиц и выходных форм анализа. Унификация (стандартизация) предполагает создание типовых методик и инструкций, стандартных программ, что обеспечивает сопоставимость результатов анализа на более высоком уровне управления, снижение затрат времени на анализ и способствует повышению его эффективности.

Организационные этапы аналитической работы:

1. Выделение субъектов и объектов анализа, выбор организационных форм их исследования и распределение обязанностей между отдельными исследователями.

2. Планирование аналитической работы.

3. Информационное и методическое обеспечение экономического анализа.

4. Аналитическая обработка данных о ходе и результатах хозяйствования.

5.Оформление результатов анализа.

6. Контроль за внедрением в производство предложений, сделанных по результатам анализа.

\section{2. Организационные формы и исполнители экономического} анализа деятельности предприятия. Организационные формы экономического анализа определяются составом аппарата и техническим уровнем управления.

На крупных промышленных предприятиях деятельностью всех экономических служб управляет главный экономист. Он организует всю экономическую работу на предприятии. На средних и мелких предприятиях возглавляет экономическую работу начальник планового 
отдела или главный бухгалтер.

Экономический анализ входит в обязанности не только работников экономических служб, но и технических отделов (главного механика, энергетика, технолога и т.д.).

Производственный отдел анализирует выполнение плана выпуска продукции по объему и ассортименту, повышение качества продукции, внедрение новой техники и технологии, комплексной механизации и автоматизации производства, расходование материальных ресурсов, общий технический и организационный уровень производства.

Отдел главного механика и энергетика изучает состояние эксплуатации машин и оборудования, выполнение планов модернизации оборудования, качество и себестоимость ремонтов, полноту использования оборудования и т.д.

Отдел технического контроля анализирует качество сырья и готовой продукции, брак и потери от брака, мероприятия по повышению качества продукции и т.д.

Отдел снабжения контролирует своевременность и качество материально-технического снабжения производства, выполнение плана поставок по объему, срокам, качеству, состояние и сохранность складских запасов и др.

Отдел сбыта изучает выполнение договоров, обязательств и планов поставок продукции потребителям по объему, качеству, срокам, состояние складских запасов и сохранность готовой продукции.

Отдел труда и заработной платы анализирует уровень организации труда, обеспеченность предприятия трудовыми ресурсами по категориям и профессиям, уровень производительности труда, использование фонда рабочего времени и фонда 3/п.

Отдел бухучета и отчетности анализирует выполнение сметы затрат на производство, себестоимость продукции, выполнение плана 
прибыли и ее использование, финансовое состояние предприятия.

Планово-экономический отдел (отдел экономического анализа) осуществляет составление плана аналитической работы и контроль за его выполнением, организует и обобщает результаты АХД предприятия и его структурных подразделений.

Периодически анализ экономики предприятия проводится вышестоящими органами управления, специалисты которых могут изучать отдельные вопросы или проводить комплексный АХД предприятия.

Вневедомственный экономический анализ выполняется статистическими, финансовыми органами, налоговыми инспекциями, банками, инвесторами, и т.д.

Предприятия могут пользоваться также услугами специалистов аудиторских и консультационных фирм.

3. Планирование аналитической работы. Важным условием, от которого зависит действенность и эффективность экономического анализа, является планомерный характер его проведения. На практике могут составляться следующие планы:

- комплексный план аналитической работы предприятия

- тематические планы.

Комплексный план обычно составляется на один год. Его разрабатывает специалист, которому на предприятии поручено руководство аналитической работой в целом. Этот план представляет собой календарное расписание отдельных экономических исследований. Кроме целей и задач анализа, в нем перечисляются вопросы, которые должны быть исследованы на протяжении года, определяется время для изучения каждого вопроса, указываются субъекты анализа, дается схема аналитического документооборота, срок и адрес поступления каждого документа, его содержание. 
В комплексном плане также должны быть предусмотрены источники информации, которые могут быть использованы при анализе, технические средства произведения анализа, и организован контроль за выполнением мероприятий.

Тематические планы - это планы проведения анализа по комплексным вопросам, которые требуют углубленного изучения. В них рассматриваются объекты, субъекты, этапы, сроки проведения анализа, его исполнители и др.

Контроль за выполнением планов анализа ведет заместитель руководителя предприятия по экономическим вопросам или лицо, на которое возложены обязанности по управлению анализом в целом.

4. Информационное обеспечение анализа. АХД базируется на использовании экономической информации. Кроме экономической в необходимых случаях используют техническую и технологическую информацию об организации производства и труда, а также социальные, психологические и правовые данные об управляемом объекте.

Экономическая информация - это совокупность сведений характеризующих экономическую сторону производства и являющихся объектом хранения, передачи и преобразования.

Создание информации должно опираться на определенные принципы:

а) выявление информационных потоков и способов наиболее эффективного их удовлетворения;

б) объективность процессов производства, обращения, использования природных, трудовых, материальных и финансовых ресурсов;

в) единство информации, поступающей из различных источников (бухгалтерского, статистического и оперативного учета); 
г) оперативность информации;

д) разработка программ использования и анализа первичной информации для целей управления.

Систему экономической информации современного предприятия можно охарактеризовать следующим образом.

Наряду с ростом объема информации осуществляется ее нехватка для принятия управленческих решений. Экономический анализ, выступая основным потребителем информационных данных должен выявить достоинства и недостатки действующей системы экономической информации.

Экономической информации присущ ряд особенностей. Как правило, она имеет прерывную во времени форму представления и отражается на материальных носителях (документах). Используя систему стоимостных, натуральных и других показателей, обязательно содержащих цифры.

Классификация информации:

I. По стадиям образования:

a) первичная, которая возникает непосредственно в ходе хозяйственной деятельности (наряды, инвентарные карточки);

б) вторичная, которая возникает в результате обработки первичной информации (бухгалтерская отчетность).

II. По функциям в процессе управления:

а) информация по конструкторской и технологической подготовке производства;

б) нормативную

в) плановую;

г) оперативную;

д) бухгалтерскую;

е) статистическую. 
III. По субъектам, проводящим анализ:

а) внутренняя (для внутреннего использования);

б) внешняя (для налоговых органов, банков).

Виды экономической информации:

1. информация по конструкторской и технологической подготовке производства:

- сведения о структуре изделия;

- сведения о затратах труда и з/п;

- сведения о нормах времени работы оборудования;

- сведения об общей стоимости единицы изделия.

2. Нормативная информация:

- технико-экономические нормы, которые определяются данными конструкторской и технологической подготовки производства;

- нормы - это максимально допустимая величина расхода сырья, материалов, и др. материальных ценностей, затрат труда на единицу продукции.

3. Плановая информация. Не изменяется в течение месяца, а иногда и года, а если есть изменения - их стремятся отразить отдельно.

4. Оперативный учет - представляет собой средство наблюдения за ходом производственных процессов и хозяйственной деятельности во время и после совершения хозяйственных и производственных операций. Его содержание определяется особенностями производства и регламентируется непосредственно на предприятии. Содержание и порядок записей данных учета должны обеспечивать с одной стороны возможность процесса, с другой стороны - передачу необходимой информации за пределы цеха или отдела.

5. Бухгалтерский учет регистрирует все операции, отражающие движение хозяйственных средств.

6. Статистический учет организует самостоятельные статистические 
сплошные и выборочные наблюдения.

7. Отчетность:

- внутримесячная;

- месячная;

- квартальная;

- годовая.

5. Подготовка и аналитическая обработка исходных данных в анализе. Подготовка информации в экономическом анализе включает следующие этапы:

1. Информация должна быть проверена на доброкачественность. Вопервых, аналитик проверяет, насколько полными являются данные, которые содержат планы и отчеты, правильно ли они оформлены, правильность арифметических подсчетов.

2. Проверка данных по существу. Определяют, насколько показатель соответствует действительности. Средства проверки: логическое осмысление данных, проверка состояния учета и обоснованности показателей разных источников.

3. Сопоставимость показателей. Для этого всю числовую информацию, после проверки ее доброкачественности, приводят в сопоставимый вид.

4. Аналитическая обработка данных - это непосредственно анализ. Организация обработки требует соответствующего методического обеспечения, определения уровня подготовки лиц, которые занимаются анализом, их обеспеченность техническими средствами проведения анализа. Аналитик обязан постоянно совершенствовать методику анализа на основе изучения достижений науки и передового опыта в области анализа и внедрять ее на всех участках производства.

6. Документальное оформление результатов анализа. Любые результаты аналитического исследования деятельности предприятия в 
целом или его подразделений должны быть оформлены в виде следующих документов.

Пояснительная записка. Составляется при направлении результатов анализа в вышестоящую организацию. Должна содержать: выводы о результатах хозяйственной деятельности и предложения по их улучшению, условия хозяйствования, уровень развития предприятия. Аналитическая часть записки должна быть конкретной по стилю, содержать аналитические расчеты, таблицы, графики и т.д. Вносимые по анализу предложения должны быть всесторонне обоснованными и направленными на улучшение результатов хозяйственной деятельности.

Справка и заключение. Их содержание может быть более конкретным, акцентированным на отражении недостатков или достижений, выявленных результатов, способов их освоения.

Бестекстовая форма оформления результатов анализа. Она состоит из постоянного макета типовых аналитических таблиц и не содержит пояснительного текста. Аналитические таблицы позволяют систематизировать, обобщать изучаемый материал и представлять его в пригодной для восприятия форме. Бестекстовый анализ повышает свою действенность потому, что при этом сокращается разрыв между выполнением анализа и использованием его результатов.

Экономический паспорт предприятия содержит наиболее существенные результаты анализа. Наличие таких данных за несколько лет позволяет рассматривать результаты хозяйственной деятельности в динамике, обеспечивает его преемственность за отдельные отрезки времени.

7. Организация компьютерной обработки экономической информации. Экономический анализ сопровождается выполнением большого разнообразия вычислений. Кроме того, в ходе анализа выполняются различные виды оценок, сравнений, группировок и др. 
операций. Результаты анализа требуют графического или табличного представления. Поэтому аналитическая обработка экономической информации является объектом автоматизации с применением современных средств связи и вычислительной техники.

Применение ПЭВМ повышает эффективность аналитической работы за счет:

- сокращения сроков проведения анализа;

- более полного охвата влияния факторов на результаты хозяйственной деятельности;

- замены приближенных расчетов точными вычислениями;

- постановки и решения новых многомерных задач анализа, практически невыполнимых вручную.

В настоящее время все предприятия испытывают потребность в расширении аналитических работ, связанных с переходом к рынку, разработкой перспектив развития, комплексной оценкой эффективности применения различных форм хозяйствования, своевременной выработкой оперативных управленческих решений. В связи с этим автоматизация экономического анализа становится объективной необходимостью.

Методика экономического анализа, ориентированная на применение ПЭВМ, должна удовлетворять требованиям системности, комплексности, оперативности, точности, прогрессивности, динамичности. Только на основе выполнения этих требований обеспечиваются познание состояния управляемого объекта и тенденций его развития, целенаправленное повышение эффективности хозяйственной деятельности по результатам анализа.

Комплексная компьютеризация анализа обеспечивает:

a) Сохранение целостности анализа. В теории АХД уже созданы основы системного комплексного анализа, обеспечивающие совместимость составных частей анализа как единого целого. Благодаря 
этому достигаются объективность и достоверность анализа.

б) ПЭВМ обеспечивает соединение процесса обработки информации с процессом принятия решений. ПЭВМ позволяют управляющему вести личный контроль над всеми стадиями процесса обработки информации, иметь возможность оценить полученные результаты и грамотно использовать их для обоснования управленческих решений.

в) ПЭВМ обеспечивает повышение оперативности и действенности анализа. Компьютерный анализ следует за учетом и превращает подсистему аналитического обеспечения управления хозяйственной деятельностью в фактор повышения эффективности производства.

В настоящее время наиболее развит компьютерный анализ в банковской сфере, а также в производственной сфере в области финансового анализа по данным бухучета.

Опыт использования этих систем позволяет обобщить основные требования к компьютерному анализу:

- своевременное и полное удовлетворение вычислительных и информационных потребностей руководителей и бухгалтеров при проведении АХД;

- минимизация времени ответа на аналитические запросы;

- возможность внесения корректив в методику расчетов;

- повторение процесса решения задач с любой точки расчета;

- простота диалога в системе «человек- машина».

В организации работы АРМ аналитика можно выделить следующие этапы:

а) подбор кадров для разработки и внедрения АРМ;

б) изучение действующей методики АХД и его организации;

в) обследование действующей информационной системы анализа;

г) постановка и описание задач комплексного АХД;

д) разработка моделей решения задач; 
е) разработка программ решения задач;

ж) внедрение АРМ аналитика в практику управления производством. Достижения в отрасли электроники создают реальные условия для углубления экономических исследований и способствуют принятию оптимальных управленческих решений. 


\section{Раздел 2. Практикум}

Тема: 1 Основы экономического анализа и его информационное обеспечение.

Проведение тестирования и обсуждение его результатов

Ход выполнения практической работы:

Выберите один или несколько правильных вариантов ответов:

Каждый правильный ответ (1 балл)

Задание \#1

Bonpoc:

Экономический анализ, как наука использует:

Выберите один из вариантов ответа:

1) теорию познания,

2) теорию неизвестности

3) этику

4)теорию косметики

\section{Задание \#2}

Bonpoc:

Бухгалтер должен владеть экономическим анализом:

Выберите один из вариантов ответа:

1) в полном объёме,

2) на уровне минимума,

3) нет необходимости,

4) совсем не нужен.

\section{Задание \#3}

Bonpoc:

Понятие анализ означает: 
Выберите один из вариантов ответа:

1) расчленение на составляющие,

2) объединение совокупности,

3) составляющие совокупность,

4) объединяющие.

\section{Задание \#4}

Bonpoc:

Принимаемое решение -это:

Выберите один из вариантов ответа:

1) без решения, нет управления,

2) нет проблем, нет решения,

3) решение как составляющая объединения,

4) решение как вид управления,

\section{Задание \#5}

Bonpoc:

Экономический анализ :

Выберите один из вариантов ответа:

1) специальная отрасль знаний,

2) обязательная отрасль знаний,

3) техническая отрасль знаний,

4) физическая отрасль знаний.

\section{Задание \#6}

Bonpoc:

Хозяйствующий субъект это:

Выберите один из вариантов ответа:

1) юридическое лицо, нет свидетельства,

2) юридическое лицо, имеет расчётный счёт,

3) юридическое лицо, не состоит на учёте, 
4) юридическое лицо без образования.

\section{Задание \#7}

Bonpoc:

Объект экономического анализа

Выберите один из вариантов ответа:

1) показатели деятельности,

2) субъекты деятельности, 3)сбор сведений, 4) обработка данных.

\section{Задание \#8}

Bonpoc:

Синтез в экономическом анализе:

Выберите один из вариантов ответа:

1) объединение составляющих элементов.

2) разъединение элементов,

3) расчленение на элементы, 4)расчленение на показатели.

\section{Задание \#9}

Bonpoc:

Предмет экономического анализа:

Выберите несколько из вариантов ответа:

1) хозяйственные процессы,

2) конечные результаты,

3) причинно-следственные связи,

4) математические формулы,

5) корреляция.

\section{Задание \#10}

Bonpoc:

Содержанием экономического анализа является:

Выберите несколько из вариантов ответа:

1) исследование явлений, процессов

2) выявление отрицательных моментов, 
3) оценка выполнения действий,4) принятие решений.

\section{Задание \#11}

Вопрос: Приёмы исследования процессов в экономике:

Выберите несколько из вариантов ответа:

1) относительные показатели,

2) средние величины,

3) сравнение,

4) функции математические.

\section{Задание \#12}

Bonpoc:

Информация в общем понятии:

Выберите один из вариантов ответа:

1) процессы в технике,

2) процессы в микронах,

3) поток сведений, о чём либо,

4) поток данных.

\section{Задание \#13}

Bonpoc:

Источники данных по АФХД

Выберите несколько из вариантов ответа:

1) учётные,

2) внеучётные,

3) текущие,

4) перспективные.

\section{Задание \#14}

Bonpoc:

Официальные документы содержат:

Выберите один из 3 вариантов ответа:

1) законы государства, указы, постановления правительства, 
2) плановые документы,

3) решения собраний,4) сведения о ресурсах.

\section{Задание \#15}

Bonpoc:

Экономическая информация:

Выберите один из 3 вариантов ответа:

1) система сведений о хозяйственной деятельности,

2) система сведений о нормированной деятельности,

3) система сведений о принципах действий,4) система сводок.

\section{Задание \#16}

Bonpoc:

Внеучётные источники это:

Выберите несколько из вариантов ответа:

1) официальные документы,

2) договоры, соглашения,

3) техническая и технологическая документация,

4) математические формулы.

\section{Задание \#17}

Bonpoc:

Плановые источники содержат:

Выберите один из 3 вариантов ответа:

1) все типы планов,

2) первичные документы,

3) сквозные задания.

\section{Задание \#18}

Bonpoc:

Задачи экономического анализа:

Выберите несколько из вариантов ответа:

1) оценка бизнес- планов, 

2) оценка производственных программ,
3) выявление резервов,
4) принятие оптимальных решений,
5) составление договора.
6) принятие соглашений.

\section{Задание \#19}

Bonpoc:

Процессы, которые изучает экономический анализ:

Выберите один из вариантов ответа:

1) документооборот,

2) снабжение, производство, реализация,

3) оборот по балансу,4) движение денежных потоков.

\section{Задание \#20}

Bonpoc:

Источники учётной информации:

Выберите несколько из вариантов ответа:

1) статистические, 2)бухгалтерские данные,

3) данные собраний, 4)протоколы учредителей.

1) (1 б.) Верные ответы: 1;

2) (1 б.) Верные ответы: 1;

3) (1 б.) Верные ответы: 1;

4) (1 б.) Верные ответы: 1;

5) (1 б.) Верные ответы: 1;

6) (1 б.) Верные ответы: 2;

7) (1 б.) Верные ответы: 1;

8) (1 б.) Верные ответы: 1;

9) (1 б.) Верные ответы: 1; 2; 3;

10) (1 б.) Верные ответы: 1; 
11) (1 б.) Верные ответы: 1:2;3.

12) (1 б.) Верные ответы: 3;

13) (1 б.) Верные ответы: 1; 2 ;

14) (1 б.) Верные ответы: 1;

15) (1 б.) Верные ответы: 1;

16) (1 б.) Верные ответы: 1; 2; 3;

17) (1 б.) Верные ответы: 1;

18) (1 б.) Верные ответы: 1,2,3,4;

19) (1 б.) Верные ответы: 2;

20) (1 б.) Верные ответы: 1; 


\section{Тема: Применение способа цепных подстановок и}

\section{арифметических разниц в решении профессиональных задач}

Задание 1. На предприятии «Олимп» наблюдается снижение объёма производства и увеличение числа работающих, руководитель предприятия дал задание экономической службе проанализировать причины такого положения. На основании исходных данных проанализировать изменение объёма производства, использовать приём абсолютных отклонений (разниц), цепных подстановок. Составить вывод.

Таблица 1.

\begin{tabular}{|l|c|c|c|}
\hline \multicolumn{1}{|c|}{ Показатели } & План & Отчет & $\begin{array}{c}\text { Абсолютное } \\
\text { отклонение }\end{array}$ \\
\hline & 1 & 2 & 3 \\
\hline $\begin{array}{l}\text { Объем производства продукции, } \\
\text { тыс. руб. (N) }\end{array}$ & 21200 & 21100 & \\
\hline $\begin{array}{l}\text { Среднесписочная численность (чел.) } \\
\text { (Ч) }\end{array}$ & 400 & 410 & \\
\hline Средняя выработка (руб.) (В) & & & \\
\hline
\end{tabular}

Методические рекомендации.

1.Найти недостающие показатели.

2.Найти абсолютное отклонение = Отчет - План.

3.Средняя выработка = Объем производства / Среднесписочная численность

4.Используем для анализа прием цепных подстановок.

Исходная формула:

$\mathrm{N}=$ Ч х В, где ч - численность количественный фактор. Вкачественный фактор.

Задание 2. Способом цепной подстановки определите степень влияния на объем розничного товарооборота магазина изменения численности работников и производительности их труда (сумма товарооборота, приходящаяся на одного работника), представив объем товарооборота как произведение численности работников на 
производительность труда. Составить вывод.

Таблица 1.

\begin{tabular}{|c|c|c|c|}
\hline Показатели & План & Отчет & Отклонение $( \pm)$ \\
\hline $\begin{array}{l}\text { Розничный товарооборот, } \\
\text { тыс. руб. }\end{array}$ & 14650 & 14840 & \\
\hline $\begin{array}{l}\text { Среднесписочная } \\
\text { численность продавцов, } \\
\text { чел. }\end{array}$ & 125 & 127 & \\
\hline $\begin{array}{l}\text { Выработка одного } \\
\text { работника, тыс. руб. }\end{array}$ & & & \\
\hline
\end{tabular}

Задание 3. Использовать приём арифметических разниц (отклонений) определите степень влияния на объем производства изменения численности работников и производительности их труда. Составить вывод.

Таблица 1.

\begin{tabular}{|c|l|c|c|c|c|}
\hline \multicolumn{2}{|c|}{ Показатели } & $\begin{array}{c}\text { Прошлый } \\
\text { период. }\end{array}$ & $\begin{array}{c}\text { Отчетный } \\
\text { период. }\end{array}$ & $\begin{array}{c}\text { Арифметическое } \\
\text { отклонение (+ ; - } \\
)\end{array}$ & $\%$ \\
\hline 1 & Объем производства, тыс. руб. (N) & 21200 & 21430 & & \\
\hline 2 & Среднесписочная численность (Ч). & 400 & 410 & & \\
\hline 3 & $\begin{array}{l}\text { Производительность труда } \\
\text { работников, руб. (В) }\end{array}$ & & & \\
\hline
\end{tabular}

Методические рекомендации.

1.Найти недостающие показатели.

2.Прием, абсолютных разниц, заключается в том, что:

2.1отклонение по количественному фактору умножают на качественный плановый или прошлый показатель,

2.2отклонение по качественному фактору умножают на количественный показатель фактический.

Ответить письменно на следующие вопросы:

Каждый правильный ответ (1 балл).

1. Перечислите виды анализа в зависимости от управления. 
2.Охарактеризовать особенности метода экономического анализа.

3.Характеристика абсолютных, относительных величин.

4. Перечислите особенности метода проведения экономического анализа.

\section{Тема: Анализ производства и реализации продукции, розничного и оптового товарооборота.}

\section{Задание 1.}

1.На основании данных рассчитать объем реализации, абсолютное отклонение, темп изменения, составить выводы, за счет каких факторов изменился объем реализации продукции.

Таблица 1 .

\begin{tabular}{|c|c|c|c|c|c|}
\hline $\begin{array}{l}\text { № } \\
\Pi \text { ח/ா }\end{array}$ & Показатели & $\begin{array}{c}\text { Прошлый } \\
\text { период }\end{array}$ & $\begin{array}{c}\text { Отчетный } \\
\text { период }\end{array}$ & $\begin{array}{l}\text { Абсолютное } \\
\text { отклонение } \\
\text { стр. } 3 \text { - гр. } 2\end{array}$ & $\begin{array}{c}\text { Темп } \\
\text { изменений \% } \\
\text { гр. 3/ гр. } 2\end{array}$ \\
\hline & 1 & 2 & 3 & 4 & 5 \\
\hline 1 & $\begin{array}{l}\text { Выпуск товарной } \\
\text { продукции, т.р. }\end{array}$ & 43000 & 45300 & & \\
\hline 2 & $\begin{array}{l}\text { Остатки нереализованной } \\
\text { продукции на начало т.р. }\end{array}$ & 700 & 400 & & \\
\hline 3 & $\begin{array}{l}\text { Остатки нереализованной } \\
\text { продукции на конец т.р. }\end{array}$ & 1400 & 1026 & & \\
\hline 4 & Объем реализации т.р. & --- & --- & & \\
\hline
\end{tabular}

$$
\text { РП - Он + B - OK }
$$

где:

РП - объем реализации;

В - выпуск продукции;

Он - остатки нереализованной продукции на начало периода на складе;

ОК - остатки неполученной продукции на конец периода на складе.

Вывод по данным таблицы № 1 (гр. 4; гр. 5).

Задание 2. 
Проанализировать выполнение плана розничного товарооборота в общем объеме по магазину. В ходе анализа объема розничного товарооборота необходимо:

1) найти процент выполнения плана товарооборота за год и по каждому кварталу;

2) определить процент роста товарооборота по сравнению с прошлым годом;

3) определить удельный вес товарооборота каждого квартала в прошлом и в отчетном году, установить поквартальную динамику;

4) дать оценку выполнения плана товарооборота за год и по кварталам;

5) сформулировать выводы по результатам анализа и внести предложения по увеличению объема товарооборота.

Таблица 1.

\begin{tabular}{|c|c|c|c|c|c|c|c|}
\hline \multirow{3}{*}{ Квартал } & \multicolumn{2}{|c|}{ Прошлый год } & \multicolumn{5}{|c|}{ Отчетный год } \\
\hline & \multirow{2}{*}{$\begin{array}{c}\text { Сумма, } \\
\text { тыс. руб. }\end{array}$} & \multirow{2}{*}{$\begin{array}{c}\text { Уд. вес, } \\
\%\end{array}$} & \multicolumn{2}{|c|}{ План } & \multicolumn{2}{|c|}{ Фактически } & \multirow{2}{*}{$\begin{array}{c}\text { Выполнение } \\
\text { плана, } \\
\text { \% }\end{array}$} \\
\hline & & & $\begin{array}{c}\text { Сумма, } \\
\text { тыс. руб. }\end{array}$ & $\begin{array}{c}\text { Уд. } \\
\text { вес, } \\
\%\end{array}$ & $\begin{array}{c}\text { Сумма, } \\
\text { тыс. руб. }\end{array}$ & $\begin{array}{c}\text { Уд. } \\
\text { вес, } \\
\% \\
\end{array}$ & \\
\hline 1 & 2 & 3 & 4 & 5 & 6 & 7 & 8 \\
\hline 1-й кв. & 4760 & 25,8 & 4915 & & 5058 & & \\
\hline 2-й кв. & 4483 & 24,3 & 4685 & & 4822 & & \\
\hline 3-й кв. & 4317 & 23,4 & 4454 & & 4566 & & \\
\hline 4-й кв. & 4890 & 26,5 & 5146 & & 5234 & & \\
\hline Итого: & 18450 & 100 & 19200 & 100 & 19680 & 100 & \\
\hline
\end{tabular}

Результаты анализа отразить в данной таблице.

Таблица 2.

\begin{tabular}{|c|c|c|c|c|c|}
\hline \multirow{2}{*}{ Квартал } & \multicolumn{2}{|c|}{$\begin{array}{c}\text { Отклонение фактич. в } \sum \\
\text { (сумме) }\end{array}$} & \multicolumn{3}{|c|}{ Отклонение в, \% } \\
\cline { 2 - 6 } & $\begin{array}{c}\text { от плана, } \\
\text { тыс. руб. }\end{array}$ & $\begin{array}{c}\text { от прошл. } \\
\text { года, тыс. руб. }\end{array}$ & $\begin{array}{l}\text { плана к } \\
\text { прошл. }\end{array}$ & $\begin{array}{c}\text { Отчётн. к } \\
\text { прошл. по уд. }\end{array}$ & $\begin{array}{c}\text { отчетн. } \\
\text { года в \% к }\end{array}$ \\
\hline
\end{tabular}




\begin{tabular}{|c|c|c|c|c|c|}
\hline & & & уд. весу & весу & плану \\
\hline 1 & 9 & 10 & 11 & 12 & 13 \\
\hline 1-й кв. & & & & & \\
\hline 2-й кв. & & & & & \\
\hline 3-й кв. & & & & & \\
\hline 4-й кВ. & & & & & \\
\hline Итого: & & & & & \\
\hline
\end{tabular}

Методические рекомендации.

1.Найти недостающие показатели.

2.Результаты анализа отразить в таблице.

\section{Задание 3.}

Анализ ассортимента, ритмичности продукции.

Проанализировать выполнение плана выпуска продукции по ассортименту ритмичности.

2. 1. Необходимым элементом аналитической работы является анализ ассортимента (номенклатуры) продукции. В зачет по ассортименту - проставляется наименьшая сумма из двух величин плана или отчета.

Коэфф . по ассортимен $\quad m y(K a)=\frac{V \text { объем в зачет по ассортимен ту }}{V \text { план }}$

где: V - выпуск продукции;

Таблица 1.

\begin{tabular}{|l|c|c|c|}
\hline $\begin{array}{c}\text { Наименование } \\
\text { продукции }\end{array}$ & По плану т. руб. & По отчету т. руб. & $\begin{array}{c}\text { В зачет по } \\
\text { ассортименту }\end{array}$ \\
\hline 1. изделие А & 8800 & 9400 & \\
\hline 2. изделие Б & 7200 & 7400 & \\
\hline 3. изделие В & 9200 & 9200 & \\
\hline 4. изделие Г & 10200 & 12000 & \\
\hline 5. изделие Д & 8000 & 7296 & \\
\hline \multicolumn{1}{|r|}{ Итого } & $?$ & $?$ & \\
\hline
\end{tabular}

Методические указания. Найти недостающие показатели и рассчитать общий коэффициент по ассортименту.

2.2. Задание 4.

Проанализировать ритмичность производства. На объем 
произведенной и реализованной продукции, ее качество и себестоимость оказывает влияние ритмичность производства.

Степень ритмичности выпуска продукции характеризуется коэффициентами ритмичности и аритмичности.

$$
\text { Коэфф .ритмичност } \quad \text { к (Кр })=\frac{V \text { по отчету в пределах плана (наименьщая величина) }}{V \text { по плану }}
$$

Таблица 1.

\begin{tabular}{|l|c|c|c|c|c|}
\hline & \multicolumn{2}{|c|}{ Выпуск по плану } & \multicolumn{2}{c|}{ Выпуск по отчету } & \multirow{2}{*}{ В пределах } \\
\cline { 2 - 4 } & т. руб. & уд. вес & т. руб. & уд. вес & плана \\
\hline I декада & 14460 & & 12000 & & \\
\hline II декада & 14440 & & 15400 & & \\
\hline III декада & 14500 & & 17896 & & \\
\hline Итого & & $100 \%$ & & $100 \%$ & \\
\hline
\end{tabular}

На основании данных таблиц 3 рассчитать недостающие показатели, удельный вес= каждая декада делится на итог. Сделать выводы по задачам 3 и 4.

Задание 5.

Ответьте письменно на следующие вопросы:

Каждый правильный ответ (1 балл)

1.Дать определение качества продукции, услуг;

2.Перечислить экономические показатели качества продукции;

3.Назвать основные причины неритмичной работы.

Тема: Анализ производства и реализации продукции, розничного и оптового товарооборота

1.Изменение эффективности использования трудовых ресурсов. $\mathrm{N}=$ Ч * В 2.Изменение эффективности использования основных средств. $\mathrm{N}=\mathrm{O} \phi^{*} Ф О$. 3.Изменение эффективности использования материальных ресурсов. $\mathrm{N}=\mathrm{PM}^{*} \mathrm{MO}$ 
где: $\mathrm{N}$ - объем выпуска продукции; Ч - численность; В - средняя выработка ОФ - основные средства; ФО - фондоотдача РМ - расход материалов ; $\mathrm{MO}$ - материалоотдача.

Задание 1.

Проанализировать влияние численности и выработки на выпуск продукции, прием цепных подстановок.

Таблица 1.

\begin{tabular}{|l|c|c|c|}
\hline \multicolumn{1}{|c|}{ Показатели } & План & Отчет & $\begin{array}{l}\text { Абсолютное } \\
\text { отклонение }\end{array}$ \\
\hline $\begin{array}{l}\text { Розничный товарооборот, тыс. руб. } \\
\text { (N) }\end{array}$ & 1 & 2 & 3 \\
\hline $\begin{array}{l}\text { Среднесписочная численность } \\
\text { (чел.) (Ч) }\end{array}$ & 400 & 4100 & \\
\hline Средняя выработка (руб.) (В) & & & \\
\hline
\end{tabular}

Используем для анализа прием цепных подстановок. Исходная формула:

$\mathrm{N}=$ Ч х В, где Ч - численность количественный фактор. В-выработка - качественный фактор. Расчетов будет три, т.к. факторов два + один. В формуле последовательно заменяют в формуле базисную (плановую) величину каждого фактора, на фактическую, все остальные остаются неизменными. Алгоритм решения:

1. $\mathrm{N}$ прошл $=$ Ч прош х В прошл.

2. $\mathrm{N}$ услов. $=$ Ч факт х В прошл

3. $\mathrm{N}$ факт $=$ Ч факт х $\mathrm{B}$ факт.

Прием абсолютных (арифметических)разниц.

Прием абсолютных разниц. Суть данного приема заключается в том, что отклонение по количественному фактору умножают на качественный базисный, прошлый (плановый) показатель. Отклонение по качественному фактору умножают на количественный показатель фактический. 
Алгоритм решения:

1) $\quad+\Delta \mathrm{Nч}=\underline{+} \Delta Ч \times \mathrm{B}$ прошл.;

2) $\pm \Delta \mathrm{NB}= \pm \Delta \Delta \mathrm{B} \times$ Ч факт.;

где, $+\Delta \mathrm{N}-$ изменение или абсолютное отклонение, (или + ), (или -), что-то одно, согласно условия заданий. Nч - изменение объема за счет численности; Nв - изменение объема за счет выработки. Составить вывод.

Задание 2.

Таблица 1 - Анализ влияния расхода материалов и материалоотдачи на выпуск продукции.

\begin{tabular}{|l|c|c|l|}
\hline \multicolumn{1}{|c|}{ Показатели } & План & Отчёт & $\begin{array}{l}\text { Абсолютная } \\
\text { разница(откло } \\
\text { нение) }\end{array}$ \\
\hline Объем производства, тыс. руб. (N) & 21200 & 21430 & \\
\hline Расход материалов, тыс. руб. (РМ) & 12330 & 12827 & \\
\hline Материалоотдача, руб. 0,000 (М/отд) & & & \\
\hline
\end{tabular}

Методические рекомендации.

Найти абсолютное отклонение $=$ Отчет - План.

Рассчитать материалоотдачу $=$ Объем производства / Расход материалов

Использовать любой прием анализа данных, по аналогии задания 1.

Составить вывод.

Задание 3.

Анализ влияния стоимости основных средств и фондоотдачи на выпуск продукции.

Таблица 1.

\begin{tabular}{|l|c|c|c|}
\hline \multicolumn{1}{|c|}{ Показатели } & План & отчёт & $\begin{array}{c}\text { Абсолютное } \\
\text { отклонение }\end{array}$ \\
\hline Объем производства, тыс. руб. (N) & 21200 & 21430 & \\
\hline $\begin{array}{l}\text { Средняя стоимость основных средств, } \\
\text { тыс. руб. (S) }\end{array}$ & 2966 & 3120 & \\
\hline Фондоотдача, руб. 0,000 (Ф/отд) & & & \\
\hline
\end{tabular}

Методические рекомендации. 
Найти абсолютное отклонение $=$ Отчет - План.

Рассчитать фондоотдачу = Объем производства / Стоимость основных средств

Использовать любой прием анализа данных, по аналогии таблиц выше.

Составить вывод.

Тема. Анализ основных средств и эффективности их использования.

Задание.1.

Проанализировать влияние материально-технической базы на товарооборот. В ходе анализа определить: фондоотдачу; фондоемкость; основные фонды на $1 \mathrm{~m}^{2}$. Основные фонды на одного человека.

Таблица 1.

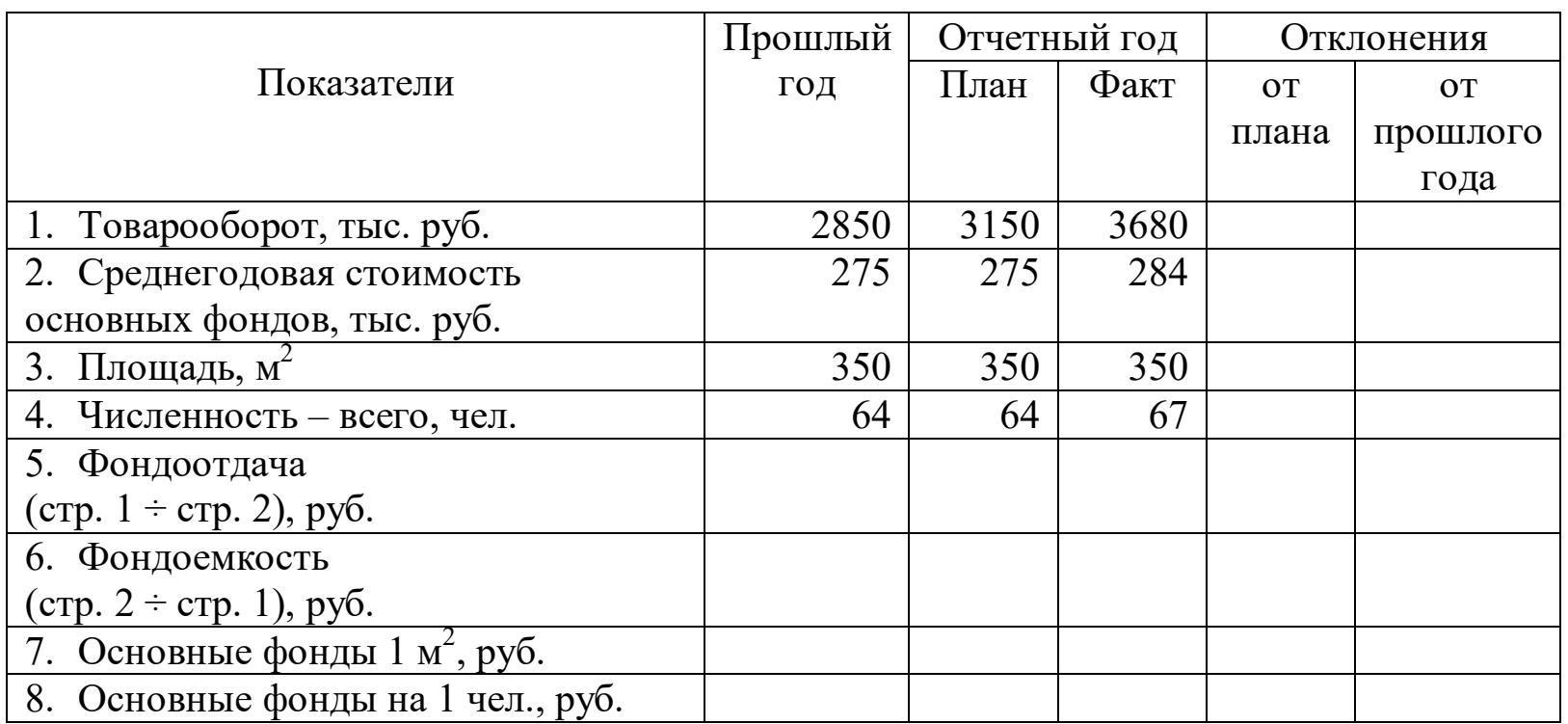

Методические указания.

1.Найти недостающие показатели.

2.Составить выводы.

Задание 2.

Проанализировать эффективность активной части основных средств. 
Таблица 1.

\begin{tabular}{|l|c|c|c|}
\hline \multicolumn{1}{|c|}{ ПОКАЗАТЕЛИ } & $\begin{array}{c}\text { Базисный } \\
\text { период }\end{array}$ & $\begin{array}{c}\text { Отчетный } \\
\text { период }\end{array}$ & Отклонение \\
\hline \multicolumn{1}{|c|}{ А } & 1 & 2 & 3 \\
\hline 1. Объем продукции, тыс. руб. (N) & 1150,0 & 1235,0 & +85 \\
\hline $\begin{array}{l}\text { 2. Средняя стоимость основных средств, } \\
\text { тыс. руб. ( S) }\end{array}$ & 910,0 & 939,0 & +29 \\
\hline 3. Средняя стоимость активной части (Sa) & 497,0 & 520,0 & +23 \\
\hline $\begin{array}{l}\text { 4. Средняя стоимость действующего } \\
\text { оборудования (S д) }\end{array}$ & 310,0 & 340,0 & +30 \\
\hline $\begin{array}{l}\text { 5. Удельный вес активной части (стр. 3 : } \\
\text { стр. 2). }\end{array}$ & & & \\
\hline $\begin{array}{l}\text { 6. Удельный вес действующего } \\
\text { оборудования в активной части (стр. 4: } \\
\text { стр. 3). }\end{array}$ & & & \\
\hline $\begin{array}{l}\text { 7. Фондоотдача оборудования (Фо) стр. 1: } \\
\text { стр. 4 }\end{array}$ & & & \\
\hline $\begin{array}{l}\text { 8. Фондоотдача основных } \\
\text { производственных средств ФО ( стр. 1: } \\
\text { стр. 2) }\end{array}$ & & & \\
\hline
\end{tabular}

Методические указания. Внимательно смотрите на обозначения.

1.Найти недостающие показатели и проанализировать эффективность использования оборудования и всех средств.

\section{2.Составить вывод.}

Задание 3.

Рассчитать показатели эффективности использования основных средств.

Таблица 1.

\begin{tabular}{|l|c|c|c|c|}
\hline \multicolumn{1}{|c|}{ Показатели } & $\begin{array}{c}\text { Базисный } \\
\text { период }\end{array}$ & $\begin{array}{c}\text { Отчетный } \\
\text { период }\end{array}$ & $\begin{array}{c}\text { Отклонение } \\
(+.-)\end{array}$ & $\begin{array}{c}\text { Темп } \\
\text { изменения }\end{array}$ \\
\hline \multicolumn{1}{|c|}{ А } & 1 & 2 & 3 & 4 \\
\hline $\begin{array}{l}\text { 1. Объем выпуска продукции, } \\
\text { тыс. руб. }\end{array}$ & 21200 & 21430 & & \\
\hline $\begin{array}{l}\text { 2. Средняя стоимость } \\
\text { основных производственных } \\
\text { средств, тыс. руб. }\end{array}$ & 2966 & 3120 & & \\
\hline 3. Фондоотдача, руб. 0,000 & & & & \\
\hline 4. Фондоемкость, руб. 0,000 & & & & \\
\hline
\end{tabular}


Методические указания.

1.Найти недостающие показатели.

2.Темпы изменения (отчёт/базис.)

3.Проанализировать показатели эффективности.

Тема. Анализ движения и технического состояния основных средств.

Проанализировать движение основных фондов и техническое состояние.

Таблица 1.

\begin{tabular}{|l|c|c|c|}
\hline \multicolumn{1}{|c|}{ Показатели } & \multicolumn{1}{|c|}{$\begin{array}{c}\text { Прошлый } \\
\text { период }\end{array}$} & $\begin{array}{c}\text { Отчетный } \\
\text { период }\end{array}$ & $\begin{array}{c}\text { Абсолютное } \\
\text { отклонение }\end{array}$ \\
\hline \multicolumn{1}{|c|}{} & $\mathbf{2}$ & $\mathbf{3}$ & $\mathbf{4}$ \\
\hline $\begin{array}{l}\text { 1. Стоимость основных фондов на } \\
\text { начало года тыс. руб. }\end{array}$ & 14500 & 13512 & \\
\hline $\begin{array}{l}\text { 2. Стоимость основных фондов на } \\
\text { конец периода тыс. руб. }\end{array}$ & 17200 & 3060 & \\
\hline $\begin{array}{l}\text { 3. Поступило основных фондов } \\
\text { тыс. руб. }\end{array}$ & 2700 & 2128 & \\
\hline $\begin{array}{l}\text { 4. сумма начисленного износа тыс. } \\
\text { руб. }\end{array}$ & 3688 & 60 & \\
\hline $\begin{array}{l}\text { 5. Продано основных фондов тыс. } \\
\text { руб. }\end{array}$ & --- & & \\
\hline 6. Коэффициент износа & & & \\
\hline 7. Коэффициент годности & & & \\
\hline 8. Коэффициент ввода & & & \\
\hline 9. Коэффициент выбытия & & & \\
\hline
\end{tabular}

Методические указания.

1.Определить и проанализировать коэффициенты движения, (К ввода и К выбытия) по периодам.

2. Определить и проанализировать коэффициенты технического состояния.

Задание 2.

Проанализировать коэффициенты износа и годности.

Таблица 1. 


\begin{tabular}{|l|c|c|c|}
\hline \multicolumn{1}{|c|}{ Показатели } & $\begin{array}{c}\text { На начало } \\
\text { периода }\end{array}$ & $\begin{array}{c}\text { На конец } \\
\text { периода }\end{array}$ & $\begin{array}{c}\text { Изменение } \\
\text { за период }\end{array}$ \\
\hline \multicolumn{1}{|c|}{ А } & 1 & 2 & 3 \\
\hline $\begin{array}{l}\text { Первоначальная стоимость основных } \\
\text { производственных средств (тыс. руб.) }\end{array}$ & 2966 & 3211 & \\
\hline Сумма износа & 890 & 975 & \\
\hline Коэффициент износа & & & \\
\hline Коэффициент годности & & & \\
\hline
\end{tabular}

Тема. Анализ показателей эффективности использования материальных ресурсов, товарных запасов

Задание 1. Проанализировать состояние запасов в сравнении с установленной нормой и рассчитать процент обеспеченности. Составить вывод.

Таблица 1

\begin{tabular}{|l|l|l|l|l|l|l|}
\hline $\begin{array}{l}\text { Наименование } \\
\text { Т.М.Ц. }\end{array}$ & $\begin{array}{l}\text { Среднедневной } \\
\text { расход }\end{array}$ & $\begin{array}{l}\text { Фактический } \\
\text { 3апас гр.3/гр2 }\end{array}$ & $\begin{array}{l}\text { Запас } \\
\text { (норматив) }\end{array}$ & $\begin{array}{l}\% \\
\text { обеспеченности } \\
\text { гр.3/гр.6*100\% }\end{array}$ \\
\cline { 2 - 7 } & м & м & дни & $\begin{array}{l}\text { Норма } \\
\text { (дни) }\end{array}$ & $\begin{array}{l}\text { Норма } \\
\text { м }\end{array}$ & \\
\hline 1 & 2 & 3 & 4 & 5 & 6 & 7 \\
\hline $\begin{array}{l}\text { Ткань } \\
\text { костюмная }\end{array}$ & 20 & 160 & & 10 & & \\
\hline
\end{tabular}

Правильно решенная задача (2 балла)

Задание 2.

Определить фактический норматив запаса в днях, если надо:

1. Среднесуточный расход материала -8 тонн.

2. Фактический запас материала - 56 тонн.

3. \% изменения норматива, если плановый норматив - 9 дней.

Правильность решения -4 балла.

Составление выводов- 1 балл. 


\section{Задание 3.}

Проанализировать влияние расхода материала и материалоотдачи на объем производства.

Таблица 1.

\begin{tabular}{|l|c|c|c|}
\hline \multicolumn{1}{|c|}{ Показатели } & $\begin{array}{c}\text { Прошл } \\
\text { ый } \\
\text { период }\end{array}$ & $\begin{array}{c}\text { Отчетный } \\
\text { период }\end{array}$ & Абсолютное отклонение \\
\hline $\begin{array}{l}\text { Объем производства, } \\
\text { тыс. руб. }\end{array}$ & 3310 & 3430 & \\
\hline $\begin{array}{l}\text { Расход материала, } \\
\text { тыс. руб. }\end{array}$ & 1690 & 1720 & \\
\hline $\begin{array}{l}\text { Материалоотдача, } \\
\text { руб. (0,000) }\end{array}$ & & \\
\hline
\end{tabular}

Методические рекомендации.

1.Найти недостающие показатели.

2.Использовать метод абсолютных разниц для проведения анализа.

3. Составить выводы.

Правильно решенная задача (2 балла)

Задание 4.

Сделайте анализ товарных запасов по данным:

Товарооборот за 1-й квартал составил 2700 тыс. руб.; товарные запасы на 01.04. - 600 тыс. руб.; норма товарных запасов на 1-й квартал 18 дней.

Тема. Оценка влияния экстенсивности и интенсивности использования материальных ресурсов на увеличение объема выпуска продукции

Задание 1. Проанализировать влияние расхода материала и материалоотдачи на объем производства, (использовать метод разниц или отклонений).

Таблица 1.

\begin{tabular}{|c|c|c|c|}
\hline Показатели & $\begin{array}{c}\text { Прошлый } \\
\text { период }\end{array}$ & $\begin{array}{c}\text { Отчетный } \\
\text { период }\end{array}$ & $\begin{array}{c}\text { Абсолютное } \\
\text { отклонение }\end{array}$ \\
\hline
\end{tabular}




\begin{tabular}{|l|c|c|c|}
\hline \multicolumn{1}{|c|}{1} & 2 & 3 & 4 \\
\hline 1. Объем производства, т. руб. & 43400 & 45300 & \\
\hline 2. Расход материалов т. руб. & 24660 & 25600 & \\
\hline 3. Материалоотдача & $?$ & $?$ & \\
\hline 4. Материалоемкость & $?$ & $?$ & \\
\hline
\end{tabular}

Методические рекомендации. Объектом анализа является абсолютное отклонение по объему производства, на данное отклонение влияет расход материалов, и материалоотдача.

Правильность решения -4 балла.

Составление выводов- 1 балл.

Задание 2. Проанализировать интенсивность использования запасов, оборачиваемость запасов.

Таблица 1.

\begin{tabular}{|l|l|l|l|}
\hline \multicolumn{1}{|c|}{ Показатели } & $\begin{array}{l}\text { Прошлый } \\
\text { период, } \\
\text { квартал }\end{array}$ & $\begin{array}{l}\text { Отчетный } \\
\text { период, } \\
\text { квартал }\end{array}$ & $\begin{array}{l}\text { Отклонение } \\
\text { от прошлого } \\
\text { периода }\end{array}$ \\
\hline & 1 & 2 & 3 \\
\hline $\begin{array}{l}\text { 1. Расход материалов в производстве (тыс. } \\
\text { руб.) (РМ) }\end{array}$ & 12330 & 12827 & \\
\hline $\begin{array}{l}\text { 2. Средние остатки материалов по балансу } \\
\text { (тыс. руб.) ( СО) }\end{array}$ & 17200 & 18100 & \\
\hline \begin{tabular}{l} 
3. Срок хранения, дни (Т) \\
\hline 4. Однодневное потребление (тыс. руб.)
\end{tabular} & & & \\
\hline $\begin{array}{l}\text { 5. Экономический результат от замедления } \\
\text { или ускорения оборачиваемости (гр. 3стр. } \\
\text { 3 х гр.2 стр. 4) }\end{array}$ & & & \\
\hline
\end{tabular}

Методические рекомендации:

Особое внимание уделяют анализу отклонений в запасах, незаполненный норматив ставит под угрозу выполнение производственной программы. При сверхнормативных запасах следует рассмотреть длительность хранения запасов, выделить сроки, пролеживания запасов более 3 -х месяцев, изучить причины, вызвавшие сверхнормативный запас, так как сверхнормативные запасы замедляют оборачиваемость оборотных активов, то есть интенсивное их 
использование, а это ухудшает финансовое состояние предприятия.

$\mathrm{T}$ срока хранения запасов $=($ Оборачиваемость $)=\mathrm{CO}$ х Д $/ \mathrm{PM}$

Тема. Анализ динамики себестоимости и издержек обращения в целом и по статьям затрат. Анализ влияния факторов на изменение уровня себестоимости и издержек обращения.

Задание 1. Проанализировать издержки обращения по ОАО «Торговый дом».

Таблица 1.

\begin{tabular}{|c|c|c|c|c|}
\hline Показатель & Прошлый год & Отчетный год & $\begin{array}{l}\text { Отклонение от } \\
\text { прошлого года }\end{array}$ & $\begin{array}{c}\text { к прошлому } \\
\text { году, в \% }\end{array}$ \\
\hline $\begin{array}{l}1 . \quad \text { Розничный } \\
\text { товарооборот в } \\
\text { действующих ценах, } \\
\text { тыс.руб. }\end{array}$ & 36295 & 41377 & & \\
\hline $\begin{array}{l}2 . \quad \text { Общая сумма } \\
\text { издержек } \\
\text { обращения, тыс.руб. }\end{array}$ & 4993 & 5586 & & \\
\hline $\begin{array}{l}3 . \quad \text { Средний } \\
\text { уровень издержек } \\
\text { обращения в \% к } \\
\text { обороту до } 0,000 \\
\text { стр.2:стр1 }\end{array}$ & & & & \\
\hline
\end{tabular}

Методические рекомендации по выполнению задания:

1.Определить средний уровень издержек обращения

2.Определить отклонение по каждому показателю (отчетный период - прошлый период)

3.Определить \% к прошлому году или динамику показателей (отчетный год делят на прошлый *100\%)

4.Составить выводы. Об изменении издержек обращения в сумме и среднему уровню.

\section{Задание 2.}

Проанализировать данные из формы 5 «3» элементы затрат.

2.1. Проанализировать абсолютное отклонение и \% снижения (удорожания) по каждому элементу в целом, и удельный вес элемента затрат в общей сумме затрат. 
Таблица 1.

\begin{tabular}{|c|c|c|c|c|c|c|}
\hline Элементы затрат & $\begin{array}{c}\text { Прошлый } \\
\text { период }\end{array}$ & $\begin{array}{c}\text { Удельны } \\
\text { й вес }\end{array}$ & $\begin{array}{l}\text { Отчетный } \\
\text { период }\end{array}$ & $\begin{array}{l}\text { Удельн } \\
\text { Ый вес }\end{array}$ & $\begin{array}{c}\text { Абсолютн } \\
\text { ое } \\
\text { отклонени } \\
\text { е } \\
\end{array}$ & $\begin{array}{c}\% \\
\text { снижен } \\
\text { ия, } \\
\text { удорож } \\
\text { ания } \\
\end{array}$ \\
\hline 1 & 2 & 3 & 4 & 5 & 6 & 7 \\
\hline $\begin{array}{l}\text { Объем производства } \\
\text { продукции т. руб. } \\
(\mathrm{N})\end{array}$ & 23000 & & 23950 & & & \\
\hline $\begin{array}{l}\text { Материальные } \\
\text { затраты т. руб. (M)3 }\end{array}$ & 7530 & & 7874 & & & \\
\hline Оплата труда т. руб. & 6600 & & 6880 & & & \\
\hline $\begin{array}{l}\text { Отчисления на } \\
\text { соц.нужды }\end{array}$ & 450 & & 473 & & & \\
\hline Амортизация & 395 & & 280 & & & \\
\hline Прочие расходы & 515 & & 513 & & & \\
\hline $\begin{array}{l}\text { Общие затраты на } \\
\text { производство тыс. } \\
\text { руб. }\end{array}$ & $?$ & $100 \%$ & $?$ & $100 \%$ & & \\
\hline $\begin{array}{l}\text { Затраты на } 1 \text { руб. } \\
\text { продукции, коп. }\end{array}$ & & & & & & \\
\hline
\end{tabular}

Задание 3. Проанализировать издержки обращения по двум

магазинам.

Таблица 1.

\begin{tabular}{|l|c|c|c|c|}
\hline \multirow{2}{*}{ Показатели } & \multicolumn{2}{|c|}{ Магазин 1 } & \multicolumn{2}{c|}{ Магазин 2 } \\
\cline { 2 - 5 } & План & Факт & План & Факт \\
\hline Товарооборот, тыс. руб. & 12650 & 13015 & 1240 & 1215 \\
\hline $\begin{array}{l}\text { Уровень расходов на продажу, } \\
\%\end{array}$ & 24,5 & & & 12,22 \\
\hline $\begin{array}{l}\text { Сумма расходов на продажу, } \\
\text { тыс. руб. }\end{array}$ & & 3115 & 128 & \\
\hline
\end{tabular}

Методические рекомендации по выполнению задания:

1.Определить средний уровень расходов на продажу, \%

2.Определить сумму расходов на продажу

3.Составить выводы. Об изменении издержек обращения в сумме и среднему уровню по магазинам.

Критерии оценки выполнения практической работы: 
Тема. Анализ состава и динамики прибыли до налогообложения. Факторный анализ валового дохода.

Задание 1. Проанализировать прибыль от продаж, до налогообложения, чистую прибыль.

Таблица 1.

\begin{tabular}{|c|c|c|c|c|c|c|}
\hline \multirow[t]{2}{*}{$\begin{array}{l}\text { № } \\
\Pi / \Pi\end{array}$} & \multirow[t]{2}{*}{ Показатели } & $\begin{array}{l}\text { Прошлый } \\
\text { период }\end{array}$ & $\begin{array}{c}\text { Структур } \\
\mathrm{a}\end{array}$ & $\begin{array}{c}\text { Отчетны } \\
\text { й } \\
\text { период }\end{array}$ & $\begin{array}{c}\text { Структур } \\
\text { a }\end{array}$ & $\begin{array}{l}\text { Абсолю } \\
\text { тное } \\
\text { отклоне } \\
\text { ние }\end{array}$ \\
\hline & & 1 & 2 & 3 & 4 & 5 \\
\hline 1 & $\begin{array}{l}\text { Выручка от продажи } \\
\text { товаров, продукции тыс. } \\
\text { руб.( без НДС,акцизов) }\end{array}$ & 22950 & - & 23460 & - & \\
\hline 2 & $\begin{array}{l}\text { Себестоимость товарной } \\
\text { продукции тыс. руб. }\end{array}$ & $(15520)$ & - & $(15860)$ & - & \\
\hline 3 & $\begin{array}{l}\text { Коммерческие расходы } \\
\text { тыс. руб. }\end{array}$ & $(118)$ & - & $(120)$ & - & \\
\hline 4 & Управленческие расходы & $(74)$ & - & $(80)$ & - & \\
\hline 5 & Прибыль от продаж & & & & & \\
\hline \multirow[t]{2}{*}{6} & a) процент к получению & --- & - & --- & - & \\
\hline & б) процент к уплате & & - & & - & \\
\hline \multirow[t]{2}{*}{7} & a) Прочие доходы & 180 & & 242 & & \\
\hline & б) Прочие расходы & 32 & & 22 & & \\
\hline 8 & $\begin{array}{l}\text { Прибыль до } \\
\text { налогообложения тыс. } \\
\text { руб. }\end{array}$ & & $100 \%$ & & $100 \%$ & \\
\hline 9 & $\begin{array}{l}\text { Текущий налог на } \\
\text { прибыль тыс. руб. }\end{array}$ & & - & & - & \\
\hline 10 & Чистая прибыль тыс. руб. & & - & & - & \\
\hline 12 & $\begin{array}{l}\text { Рентабельность } \\
\text { продукции (\%), продаж }\end{array}$ & & - & & - & \\
\hline
\end{tabular}

Методические рекомендации.

1.Рассчитать недостающие показатели.

2. Структуру прибыли от продаж, прочие доходы и расходы в сумме прибыли до налогообложения.

3.Составить выводы.

ЗАДАНИЕ 2. Проанализировать выполнение плана по прибыли. Составить выводы.

Таблица 1. 


\begin{tabular}{|l|r|r|r|}
\hline \multicolumn{1}{|c|}{ Показатели } & \multicolumn{1}{|c|}{ План } & Отчёт & Отклонение $( \pm)$ \\
\hline 1. Товарооборот, тыс. руб. & 7360 & 7640 & \\
\hline 2. Валовой доход, тыс. руб. & 1950,4 & & \\
\hline 3. Уровень валового дохода, \% & 26,5 & 28,4 & \\
\hline 4. Расходы на продажу, тыс. руб. & & 1466,9 & \\
\hline 5. Уровень расходов на продажу, \% & & & \\
\hline 6. Прибыль от продажи, тыс. руб. & & & \\
\hline 7. Рентабельность от продажи, \% & & & \\
\hline
\end{tabular}

Методические рекомендации.

1.Рассчитать недостающие показатели. 2. Проанализировать выполнение плана по прибыли. прибыль. 3. Проанализировать рентабельность продаж.

\section{2.Составить выводы.}

ЗАДАНИЕ 3. Проанализировать влияние объема товарооборота и среднего уровня торговой наценки на выполнение плана валового дохода, по результатам анализа сделайте выводы.

Таблица 1.

\begin{tabular}{|c|c|c|c|c|}
\hline \multirow[b]{2}{*}{ Показатели } & \multicolumn{3}{|c|}{ Отчетный год } & \multirow{2}{*}{$\begin{array}{c}\text { Абсолютное } \\
\text { отклонение от } \\
\text { плана, }(+)\end{array}$} \\
\hline & План & отчёт & $\begin{array}{c}\text { \% выполнения } \\
\text { плана }\end{array}$ & \\
\hline Товарооборот, тыс. руб. & 16280 & 16930 & & \\
\hline $\begin{array}{l}\text { Валовой доход: } \\
\text { 1) в сумме, тыс. руб. }\end{array}$ & & 3190 & & \\
\hline 2) уровень, \% & 18,5 & & & \\
\hline
\end{tabular}

Методические рекомендации.

1.Рассчитать недостающие показатели.

2.Составить выводы.

Тема. Факторный анализ прибыли от продаж и рентабельности. Резервы увеличения финансовых результатов.

Задание 1. Факторный анализ отклонения рентабельности продукции (метод цепных подстановок), алгоритм решения.

Использовать данные таблицы задания 1, практическая работа12.

Таблица 1. 


\begin{tabular}{|c|c|c|c|c|}
\hline \multirow{2}{*}{$\begin{array}{c}\text { № } \\
\text { подстановки }\end{array}$} & \multicolumn{2}{|c|}{ Факторы } & \multirow[t]{2}{*}{ Рентабельность } & \multirow{2}{*}{$\begin{array}{c}\text { Расчет влияния } \\
\text { факторов }\end{array}$} \\
\hline & $\begin{array}{c}\text { Прибыль от } \\
\text { продаж }\end{array}$ & $\begin{array}{c}\text { Выручка от } \\
\text { продаж }\end{array}$ & & \\
\hline № 1 & $\begin{array}{l}\text { прошлый } \\
\text { период }\end{array}$ & $\begin{array}{l}\text { прошлый } \\
\text { период }\end{array}$ & R прошлый & \\
\hline № 2 & $\begin{array}{l}\text { отчетный } \\
\text { период }\end{array}$ & $\begin{array}{l}\text { прошлый } \\
\text { период }\end{array}$ & $\mathrm{R}_{2}$ & $\begin{array}{l}\mathrm{R}_{2} \square \mathrm{R} \text { прошлый, } \\
\text { влияние прибыли }\end{array}$ \\
\hline № 3 & $\begin{array}{l}\text { отчетный } \\
\text { период }\end{array}$ & $\begin{array}{l}\text { отчетный } \\
\text { период }\end{array}$ & R отчетный & $\begin{array}{l}\mathrm{R} \text { отчетный } \square 2 \text {, } \\
\text { влияние выручки } \\
\text { от продаж }\end{array}$ \\
\hline
\end{tabular}

Методические рекомендации.

1.Использовать данные, практической работы12, задания 1.

2. Составить выводы.

Задание 2. Проанализировать влияние объема товарооборота и среднего уровня торговой наценки на выполнение плана валового дохода.

Таблица 1.

\begin{tabular}{|l|r|r|r|r|}
\hline \multirow{2}{*}{ Показатели } & \multicolumn{3}{|c|}{ Отчетный год } & Отклонение от \\
\cline { 2 - 4 } & План & Факт. & $\begin{array}{c}\text { \% выполнения } \\
\text { плана }\end{array}$ & $\begin{array}{l}\text { плана, (+) } \\
\text { Товарооборот, тыс. руб. }\end{array}$ \\
\hline $\begin{array}{l}\text { Валовой доход: } \\
\text { в сумме, тыс. руб. }\end{array}$ & 16280 & 16930 & & \\
\hline уровень, \% & 18,5 & 3190 & & \\
\hline
\end{tabular}

Методические рекомендации.

1.Рассчитать недостающие показатели. Составить выводы.

Задание 3. Проанализировать влияние на прибыль от продажи изменения товарооборота, уровня валового дохода, уровня расходов на продажу.

Таблица 1.

\begin{tabular}{|l|r|r|r|}
\hline \multicolumn{1}{|c|}{ Показатели } & \multicolumn{1}{|c|}{ План } & \multicolumn{1}{|c|}{ Факт. } & $\begin{array}{c}\text { Абсолютное } \\
\text { отклонение }( \pm)\end{array}$ \\
\hline 1.Товарооборот, тыс. руб. & 7360 & 7640 & \\
\hline 2.Валовой доход, тыс. руб. & 1950,4 & & \\
\hline 3.Уровень валового дохода, \% & 26,5 & 28,4 & \\
\hline 4.Расходы на продажу, тыс. руб. & & & 1466,9 \\
\hline 5.Уровень расходов на продажу, \% & & & \\
\hline
\end{tabular}




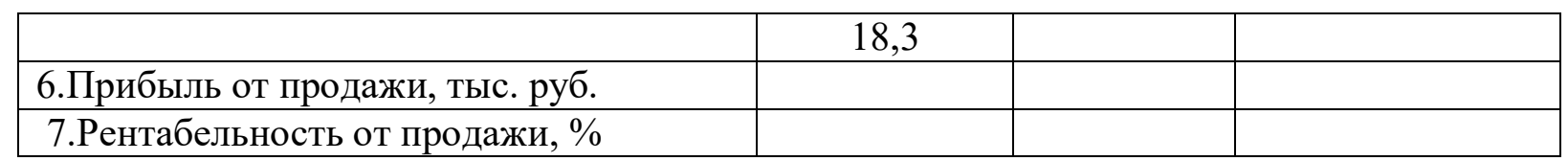

Методические рекомендации.

1.Рассчитать недостающие показатели, составить выводы.

Задание 4. Проанализировать факторы, влияющие на прибыль отчетного периода, (изменение объема выручки, себестоимости, цен, структуры продукции).

Таблица 1.

\begin{tabular}{|l|l|l|l|}
\hline \multicolumn{1}{|c|}{ Показатели } & $\begin{array}{l}\text { Прошлый } \\
\text { период }\end{array}$ & $\begin{array}{l}\text { Отчетные } \\
\text { данные в ценах } \\
\text { прошлого } \\
\text { периода }\end{array}$ & $\begin{array}{l}\text { Отчетный } \\
\text { период }\end{array}$ \\
\hline $\begin{array}{l}\text { 1. Выручка от реализации продукции (без } \\
\text { НДС, акцизов) тыс. руб. }\end{array}$ & 61278 & 59456 & 59478 \\
\hline $\begin{array}{l}\text { 2. Полная себестоимость реализации } \\
\text { продукции тыс. руб. }\end{array}$ & 57146 & 56856 & 56816 \\
\hline 3.Прибыль от продаж, тыс. руб. & & & \\
\hline \begin{tabular}{l} 
4.Уровень рентабельности продукции, $\%$ \\
\hline
\end{tabular} & & & \\
\hline
\end{tabular}

Методические рекомендации.

1.Рассчитать недостающие показатели, составить выводы.

Ответьте письменно на следующие вопросы.

Каждый правильный ответ (1 балл)

1.Факторы, влияющие на прибыль.

2.Резервы увеличения прибыли, рентабельности.

Тема: Анализ имущества и источников его формирования

Задание 1. Заполнить таблицу данными из баланса и проанализировать состав имущества.

Таблица 1.

\begin{tabular}{|l|l|l|l|}
\hline \multicolumn{1}{|c|}{ Актив } & Код строки & \multicolumn{1}{|c|}{$\begin{array}{c}\text { Отчетный } \\
\text { период на 31 } \\
\text { декабря 2015г. }\end{array}$} & $\begin{array}{l}\text { Прошлый } \\
\text { период на 31 } \\
\text { декабря 2014г. }\end{array}$ \\
\hline 1.Внеоборотные активы & \multicolumn{3}{|l|}{} \\
\hline Нематериальные активы & 1110 & 204 & 114 \\
\hline
\end{tabular}




\begin{tabular}{|l|l|l|l|}
\hline Основные средства & 1150 & 900 & 750 \\
\hline Доходные вложения & 1160 & 230 & 350 \\
\hline Финансовые вложения & 1170 & 400 & 400 \\
\hline Прочие внеоборотные активы & 1190 & & \\
\hline Итого по разделу 1 & 1100 & 1734 & 1614 \\
\hline 2.Оборотные активы & & & \\
\hline Запасы & 1210 & 1145 & 1309 \\
\hline НДС по приобретенным ценностям & 1220 & 43 & 35 \\
\hline Дебиторская задолженность & 1230 & 610 & 426 \\
\hline Денежные средства & 1250 & 580 & 235 \\
\hline Прочие оборотные активы & 1260 & & \\
\hline Итого по разделу 2 & 1200 & 2378 & 2005 \\
\hline БАЛАНС & 1600 & 4112 & 3619 \\
\hline ПАССИВ & & & \\
\hline 3.Капитал и резервы & & & 1765 \\
\hline Уставный капитал & 1310 & 1890 & \\
\hline Добавочный капитал & 1350 & & 174 \\
\hline Резервный капитал & 1360 & 159 & \\
\hline Нераспределенная прибыль & 1370 & 83 & 1939 \\
\hline Итого по разделу 3 & 1300 & 2132 & 300 \\
\hline 4.Долгосрочные обязательства & 1400 & 320 & \\
\hline 5.Краткосрочные обязательства & & & 850 \\
\hline Займы и кредиты & 1510 & 887 & 530 \\
\hline Кредиторская задолженность & 1520 & 773 & - \\
\hline Доходы будущих периодов & 1530 & - & 1380 \\
\hline Прочие краткосрочные обязательства & 1550 & - & \\
\hline Итого по разделу 5 & 1500 & 1660 & \\
\hline БАЛАНС & 1700 & 4112 & \\
\hline
\end{tabular}

\begin{tabular}{|l|c|c|c|c|c|c|}
\hline & \multicolumn{3}{|c|}{ Сумма } & \multicolumn{3}{c|}{ Структура \% } \\
\cline { 2 - 6 } & $\begin{array}{c}\text { за } \\
\text { прошлый } \\
\text { период } \\
\text { (тыс. } \\
\text { руб.) }\end{array}$ & $\begin{array}{c}\text { За } \\
\text { отчётный } \\
\text { период } \\
\text { (тыс. } \\
\text { руб.) }\end{array}$ & изменение & $\begin{array}{c}\text { за } \\
\text { прошлый } \\
\text { период }\end{array}$ & $\begin{array}{c}\text { За } \\
\text { отчётный } \\
\text { период }\end{array}$ & изменение \\
\hline $\begin{array}{l}\text { Внеоборотные } \\
\text { активы 1 р. }\end{array}$ & & & & & & \\
\hline $\begin{array}{l}\text { Оборотные } \\
\text { активы 2p. }\end{array}$ & & & & & & \\
\hline Итого имущества & & & & & \\
\hline
\end{tabular}

Методические рекомендации.

1.Рассчитать недостающие показатели, составить выводы, отразить изменение имущества в абсолютной сумме и процентах, а также за счет каких активов это произошло по общей стоимости имущества; стоимости иммобилизованных (внеоборотных средств); стоимости мобильных 
(оборотных) активов;

Задание 2. Заполнить таблицу данными из баланса и проанализировать источники формирования имущества.

Таблица 1.

\begin{tabular}{|l|r|c|l|l|l|l|}
\hline & \multicolumn{3}{|c|}{ Сумма } & \multicolumn{3}{|c|}{ Структура \% } \\
\cline { 2 - 7 } & $\begin{array}{c}\text { за } \\
\text { прошлый } \\
\text { период } \\
\text { (тыс. } \\
\text { руб.) }\end{array}$ & $\begin{array}{c}\text { За } \\
\text { отчётный } \\
\text { период } \\
\text { (тыс. } \\
\text { руб.) }\end{array}$ & изменение & $\begin{array}{c}\text { 3а } \\
\text { прошлый } \\
\text { период }\end{array}$ & $\begin{array}{c}\text { За } \\
\text { отчётный } \\
\text { период }\end{array}$ & изменение \\
\hline $\begin{array}{l}\text { Капитал } \\
\text { резервы } \\
\text { (собствен.) }\end{array}$ & (III) & & & & & \\
\hline $\begin{array}{l}\text { Засмные } \\
\text { источники (IV + } \\
\text { V) }\end{array}$ & & & & & & \\
\hline Итого источников & & & & & & \\
\hline
\end{tabular}

Методические рекомендации.

1.Рассчитать недостающие показатели, составить выводы, отразить изменение источников как собственных, так и заемных в абсолютной сумме и по удельному весу, величины собственного капитала; величины заемного капитала; а также указать за счет, каких источников было приобретение, создание имущества.

Задание 3. Составить баланс: 1) Внеоборотные активы - 1734; 5) Долгосрочные обязательства - 320; 2) Производственные запасы - 602; 6) Краткосрочные обязательства - 808;

3) Готовая продукция - 315; 7) Денежные средства - 409; 4) Капитал и резервы - 1932

Выбрать правильный ответ: Правильность решения 1 балл.

\section{1.Показатели оценки имущества :}

а). сумма задолженности,

б). реальный производственный капитал

в). Остатки готовой продукции 


\section{2. к внеоборотным активам :}

а) материальные активы, дебиторская задолженность и нематериальные активы,

б) материальные активы и долгосрочные финансовые вложения,

в) нематериальные активы и долгосрочные финансовые вложения.

К долгосрочным пассивам :

а) долгосрочные займы,

б) долгосрочные кредиты,

в) оба вышеупомянутых.

Тема. Анализ финансовой устойчивости.

Задание 1. Определить и проанализировать оборотный капитал, коэффициенты финансовой устойчивости.

Таблица1.

\begin{tabular}{|l|c|c|c|}
\hline \multicolumn{1}{|c|}{ Показатели } & $\begin{array}{c}\text { За прошлый } \\
\text { период (тыс. } \\
\text { руб.) }\end{array}$ & $\begin{array}{c}\text { За отчётный } \\
\text { период (тыс. } \\
\text { руб.) }\end{array}$ & $\begin{array}{c}\text { Абсолютное } \\
\text { отклонение }\end{array}$ \\
\hline 1. Капитал и резервы & & & \\
\hline 2. Долгосрочные пассивы & & & \\
\hline 3. Внеоборотные активы & & & \\
\hline $\begin{array}{l}\text { 4. Наличие собственных оборотных } \\
\text { средств (Н.С.О.С.) }\end{array}$ & & & \\
\hline 5. Запасы и затраты(НДС) & & \\
\hline 6. Излишек или недостаток & & \\
\hline $\begin{array}{l}\text { 7. Сумма нормальных источников по } \\
\text { балансу + Н.С.О.С. (стр. 4 данной } \\
\text { таблицы.) }\end{array}$ & & & \\
\hline 8. Излишек, недостаток & & \\
\hline $\begin{array}{l}\text { 9. Коэффициент обеспеченности } \\
\text { запасов и затрат 0,1 }\end{array}$ & & & \\
\hline 10. Тип финансовой устойчивости & & & \\
\hline $\begin{array}{l}\text { 11. Коэффициент маневренности до } \\
\text { 0,5 }\end{array}$ & & & \\
\hline 12. Коэффициент риска (норма < 1) & & & \\
\hline $\begin{array}{l}\text { 13. Коэффициент независимости 0,5- } \\
\text { 0,8. }\end{array}$ & & & \\
\hline
\end{tabular}

Методические рекомендации.

1.Рассчитать недостающие показатели, составить выводы об 
изменении оборотного капитала, финансовой устойчивости.

Тема. Составление и анализ платёжного баланса.

Таблица1.

\begin{tabular}{|c|c|c|c|c|c|c|c|}
\hline \multirow{2}{*}{$\begin{array}{c}\text { Актив } \\
\text { (покрытие) A }\end{array}$} & \multirow{2}{*}{$\begin{array}{c}\text { За } \\
\text { прошлы } \\
\text { й } \\
\text { период } \\
\text { (тыс. } \\
\text { руб.) }\end{array}$} & \multirow{2}{*}{$\begin{array}{c}\text { За } \\
\text { отчётны } \\
\text { й } \\
\text { период } \\
\text { (тыс. } \\
\text { руб.) }\end{array}$} & \multirow{2}{*}{$\begin{array}{c}\text { Пассив } \\
\text { (обязательства) } \\
\text { П }\end{array}$} & \multirow{2}{*}{$\begin{array}{c}\text { За } \\
\text { про- } \\
\text { шлый } \\
\text { пе- } \\
\text { риод } \\
\text { (тыс. } \\
\text { руб.) }\end{array}$} & \multirow{2}{*}{$\begin{array}{c}\text { За } \\
\text { отчётн } \\
\text { ый } \\
\text { перио } \\
\text { д } \\
\text { (тыс. } \\
\text { руб.) } \\
\end{array}$} & \multicolumn{2}{|c|}{$\begin{array}{c}\text { Платежный из- } \\
\text { лишек } \\
\text { (недостаток) }\end{array}$} \\
\hline & & & & & & $\begin{array}{c}\text { На } \\
\text { начало } \\
\text { периода }\end{array}$ & $\begin{array}{l}\text { На } \\
\text { конец } \\
\text { перио } \\
\text { да }\end{array}$ \\
\hline $\begin{array}{l}\text { 1. Наиболее } \\
\text { ликвидные } \\
\text { активы (стр. ) } \\
\text { A }_{1} \\
\end{array}$ & & & $\begin{array}{l}\text { 1. Наиболее } \\
\text { срочные обяза- } \\
\text { тельства (стр.) } \\
\Pi_{1}\end{array}$ & & & & \\
\hline $\begin{array}{l}\text { 2. Быстро- } \\
\text { реализуемые } \\
\text { активы (стр. ) } \\
\text { A2 }_{2}\end{array}$ & & & $\begin{array}{l}2 . \\
\text { Краткосрочные } \\
\text { обязательства } \\
\text { (стр.) } \Pi_{2}\end{array}$ & & & & \\
\hline $\begin{array}{l}\text { 3. Медленно- } \\
\text { реализуемые, } \\
\text { (стр. ) } A_{3}\end{array}$ & & & $\begin{array}{l}3 . \\
\text { Долгосрочные } \\
\text { обязательства } \\
\text { (стр. ) П } 3\end{array}$ & & & & \\
\hline $\begin{array}{l}\text { 4. Трудно- } \\
\text { реализуемые } \\
\text { активы (стр. ) } \\
\text { A }_{4}\end{array}$ & & & $\begin{array}{l}\text { 4. Постоянные } \\
\text { пассивы } \\
\text { (капитал и } \\
\text { резервы) (стр.) } \\
\Pi_{4}\end{array}$ & & & & \\
\hline Баланс & & & Баланс & & & & \\
\hline
\end{tabular}

Методические рекомендации.

1.Заполнить данными платежный баланс.

2Определить излишек или недостаток средств.

3.Записать условие ликвидности данного баланса и сравнить с нормой.

4. Ответить на следующие вопросы:

Тема. Анализ платёжеспособности предприятия, деловой активности

Таблица1.

\begin{tabular}{|c|c|c|c|c|l|}
\hline Актив & $\begin{array}{c}\text { За } \\
\text { прошлый }\end{array}$ & $\begin{array}{c}\text { За } \\
\text { отчётный }\end{array}$ & Пассив & $\begin{array}{l}\text { За } \\
\text { прошлый }\end{array}$ & $\begin{array}{l}\text { За } \\
\text { отчётный }\end{array}$ \\
\hline
\end{tabular}




\begin{tabular}{|c|c|c|c|c|c|}
\hline & $\begin{array}{c}\text { период } \\
\text { (тыс. } \\
\text { руб.) }\end{array}$ & $\begin{array}{c}\text { период } \\
\text { (тыс. } \\
\text { руб.) }\end{array}$ & & $\begin{array}{l}\text { период } \\
\text { (тыс. } \\
\text { руб.) }\end{array}$ & $\begin{array}{l}\text { период } \\
\text { (тыс. } \\
\text { руб.) }\end{array}$ \\
\hline $\begin{array}{l}1 . \\
\text { ликвидные средства, } \\
\text { денежные } \\
\text { краткосрочные } \\
\text { финансовые } \\
\text { вложения. }\end{array}$ & & & $\begin{array}{l}\text { 1.Наиболее } \\
\text { срочные пассивы, } \\
\text { кредиторская } \\
\text { задолженность и } \\
\text { прочие пассивы, } \\
\text { дивиденды. }\end{array}$ & & \\
\hline $\begin{array}{l}2 . \\
\text { Быстрореализуемая } \\
\text { задолженность } \\
\text { (дебиторы) до } 12 \\
\text { мес. }\end{array}$ & & & $\begin{array}{l}\text { 2. Краткосрочные } \\
\text { кредиты, займы. }\end{array}$ & & \\
\hline $\begin{array}{l}3 . \text { Медленно } \\
\text { реализуемые запасы, } \\
\text { затраты, дебиторы } \\
\text { свыше } 12 \text { мес. }\end{array}$ & & & $\begin{array}{l}\text { 3. Долгосрочные } \\
\text { кредиты } \\
\text { обязательства }\end{array}$ & & \\
\hline $\begin{array}{l}4 . \\
\text { Труднореализуемые } \\
\text { основные средства, } \\
\text { нематериальные } \\
\text { активы, } \\
\text { незавершенное } \\
\text { производство, } \\
\text { оборудование } \\
\text { установке }\end{array}$ & & & $\begin{array}{l}\text { 4.Постоянные } \\
\text { пассивы (капитал } \\
\text { и резервы) - из } \\
\text { баланса }\end{array}$ & & \\
\hline
\end{tabular}

Задание 2. Рассчитать и проанализировать коэффициенты платёжеспособности.

Таблица1 - Анализ краткосрочной платёжеспособности.

\begin{tabular}{|l|c|c|c|c|}
\hline \multicolumn{1}{|c|}{ Показатели } & $\begin{array}{c}\text { Норма } \\
\text { коэф-та }\end{array}$ & $\begin{array}{c}\text { На начало } \\
\text { периода }\end{array}$ & $\begin{array}{c}\text { На конец } \\
\text { периода }\end{array}$ & $\begin{array}{c}\text { Изменения } \\
\text { за год }\end{array}$ \\
\hline \multicolumn{1}{|c|}{ А } & 1 & 2 & 3 & 4 \\
\hline $\begin{array}{l}\text { 1. Коэффициент абсолютной } \\
\text { ликвидности }\end{array}$ & $0,2-0,25$ & & & \\
\hline $\begin{array}{l}\text { 2. Коэффициент } \\
\text { промежуточного покрытия } \\
\text { (критической ликвидности) }\end{array}$ & $0,6-1$ & & & \\
\hline $\begin{array}{l}\text { 3. Коэффициент общего } \\
\text { покрытия (текущей } \\
\text { ликвидности) }\end{array}$ & $2-2,5$ & & & \\
\hline
\end{tabular}


Задание 3. Проанализировать показатели д оборачиваемости активов

Таблица1.

\begin{tabular}{|l|c|l|c|}
\hline \multicolumn{1}{|c|}{ Показатели } & \multicolumn{1}{|c|}{$\begin{array}{c}\text { Прошлый } \\
\text { период }\end{array}$} & $\begin{array}{c}\text { Отчетный } \\
\text { период }\end{array}$ & $\begin{array}{c}\text { Абсолютное } \\
\text { отклонение }\end{array}$ \\
\hline Выручка от реализации тыс. руб. & 29720 & 34430 & \\
\hline $\begin{array}{l}\text { Средние остатки оборотных активов } \\
\text { (баланс), ф. № 1 тыс. руб. }\end{array}$ & 20800 & 21690 & \\
\hline $\begin{array}{l}\text { Кол-во дней анализируемого } \\
\text { периода,180дней }\end{array}$ & & & \\
\hline К оборачиваемости & $\mathrm{X}$ & & \\
\hline Продолжительность оборота (дней) & & & \\
\hline $\begin{array}{l}\text { Сумма средств, вложенных или } \\
\text { высвободившихся тыс. руб. }\end{array}$ & & & \\
\hline
\end{tabular}

Задание 4. За отчетный квартал выручка от реализации продукции составила 168500 тыс. руб., оборачиваемость в прошлом квартале 48 дней, в отчетном - 52 дня. Узнать сумму вложенных и высвободившихся средств из оборота. 


\section{Литература}

1. Агеева, О. А. Бухгалтерский учет и анализ в 2 ч. Часть 2. Экономический анализ: учебник для вузов/ О.А. Агеева, Л. С. Шахматова. - Москва : Издательство Юрайт, 2020. - 240 с. (Высшее образование). — ISBN 978-5-534-04061-6. - Текст : электронный // ЭБС Юрайт [сайт]. — URL: https://urait.ru/bcode/452528

2. Войтоловский, Н. В. Экономический анализ : учебник для академического бакалавриата / Н. В. Войтоловский, А. П. Калинина, И. И. Мазурова ; под редакцией Н. В. Войтоловского, А. П. Калининой, И. И. Мазуровой. - 5-е изд., перераб. и доп. - Москва : Издательство Юрайт, 2015. - 620 с. - (Бакалавр. Академический курс). - ISBN 978-59916-4229-3. - Текст : электронный // ЭБС Юрайт [сайт]. — URL: https://urait.ru/bcode/381534

3. Казакова, Н. А. Анализ финансовой отчетности. Консолидированный бизнес : учебник для вузов / Н. А. Казакова. Москва : Издательство Юрайт, 2020. — 233 с. — (Высшее образование). ISBN 978-5-534-10602-2. — Текст : электронный // ЭБС Юрайт [сайт]. URL: https://urait.ru/bcode/456425

4. Кулагина, Н. А. Анализ и диагностика финансовохозяйственной деятельности предприятия. Практикум : учебное пособие для вузов / Н. А. Кулагина. - 2-е изд., перераб. и доп. - Москва : Издательство Юрайт, 2020. - 135 с. - (Высшее образование). ISBN 978-5-534-07835-0. — Текст : электронный // ЭБС Юрайт [сайт]. — URL: https://urait.ru/bcode/453800

5. Румянцева, Е. Е. Экономический анализ : учебник и практикум для вузов / Е. Е. Румянцева. - Москва : Издательство Юрайт, 2020. 381 с. - (Высшее образование). - ISBN 978-5-534-12670-9. — Текст : электронный // ЭБС Юрайт [сайт]. — URL: https://urait.ru/bcode/450731 
6. Шадрина, Г. В. Теория экономического анализа : учебник и практикум для вузов / Г. В. Шадрина. - Москва : Издательство Юрайт, 2020. - 208 с. - (Высшее образование). - ISBN 978-5-534-01203-3. Текст : электронный // ЭБС Юрайт [сайт]. - URL: https://urait.ru/bcode/452781

7. Шадрина, Г. В. Управленческий и финансовый анализ : учебник и практикум для вузов / Г. В. Шадрина. - Москва : Издательство Юрайт, 2020. - 316 с. - (Высшее образование). - ISBN 978-5-534-012842. - Текст : электронный // ЭБС Юрайт [сайт]. - URL: https://urait.ru/bcode/452783

8. Шадрина, Г. В. Экономический анализ : учебник и практикум для вузов / Г. В. Шадрина. - 2-е изд., перераб. и доп. - Москва : Издательство Юрайт, 2020. - 431 с. - (Высшее образование). ISBN 978-5-534-04115-6. - Текст : электронный // ЭБС Юрайт [сайт]. URL: https://urait.ru/bcode/450141

9. Экономический анализ в 2 ч. Часть 1. : учебник для вузов/ Н. В. Войтоловский [и др.] ; под редакцией Н. В. Войтоловского, А. П. Калининой, И. И. Мазуровой. - 7-е изд., перераб. и доп. - Москва : Издательство Юрайт, 2020. - 291 с. - (Высшее образование). ISBN 978-5-534-10997-9. — Текст : электронный // ЭБС Юрайт [сайт]. — URL: https://urait.ru/bcode/454211

10. Экономический анализ в 2 ч. Часть 2. : учебник для вузов / Н. В. Войтоловский [и дp.] ; под редакцией Н. В. Войтоловского, А. П. Калининой, И. И. Мазуровой. - 7-е изд., перераб. и доп. - Москва : Издательство Юрайт, 2020. - 302 с. - (Высшее образование). ISBN 978-5-534-10999-3. — Текст : электронный // ЭБС Юрайт [сайт]. URL: https://urait.ru/bcode/454212 


\title{
Скрипникова Галина Васильевна
}

\section{ЭКОНОМИЧЕСКИЙ АНАЛИЗ}

\author{
Учебное пособие \\ для студентов экономических направлений подготовки \\ бакалавриата
}

Книга издана в авторской редакичии.

Дизайн обложки: Р.В. Орлов

Доступ к пособию - свободный.

Режим доступа: http://nkras.ru/arhiv/2021/SkripnikovaGV.pdf

Пособие содержится в едином файле PDF.

Дата выхода в свет 12.03.2021.

Свободная цена. Заказ ЭА1203/21.

По вопросам приобретения и издания литературы обращаться по адресу:

Издательство НИЦ

ул. 9 Мая, 5/192, г. Красноярск, 660127 Россия

тел. +7 (923) 358-10-20

Электронная почта: monography@nkras.ru

Дополнительная информация на сайте: www.nkras.ru 


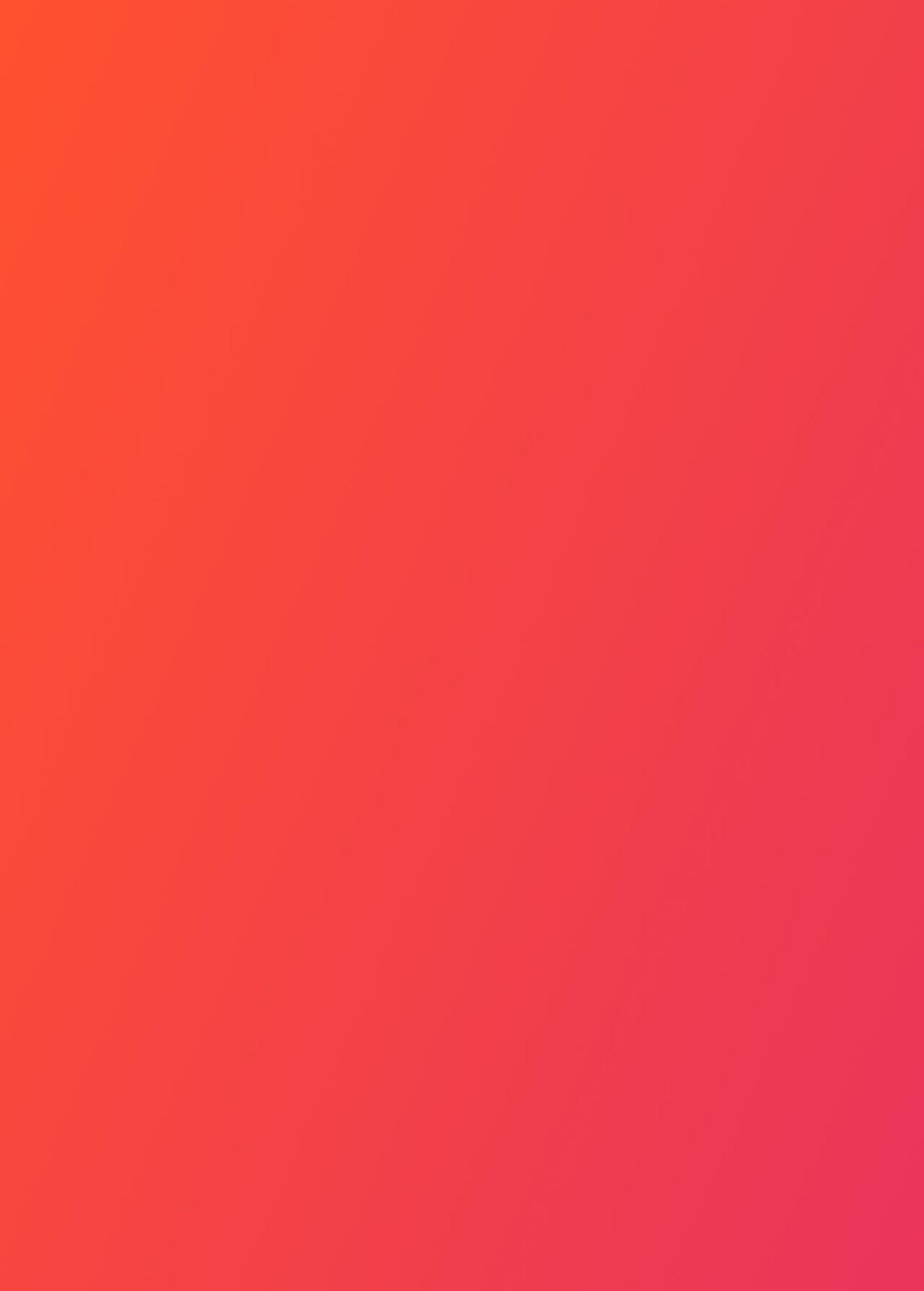

